DVERSION WEIRS AND FISH PASSACES FOR SMALL-SCALE IRRIGATION Lao People's Democratic Republic September 2020

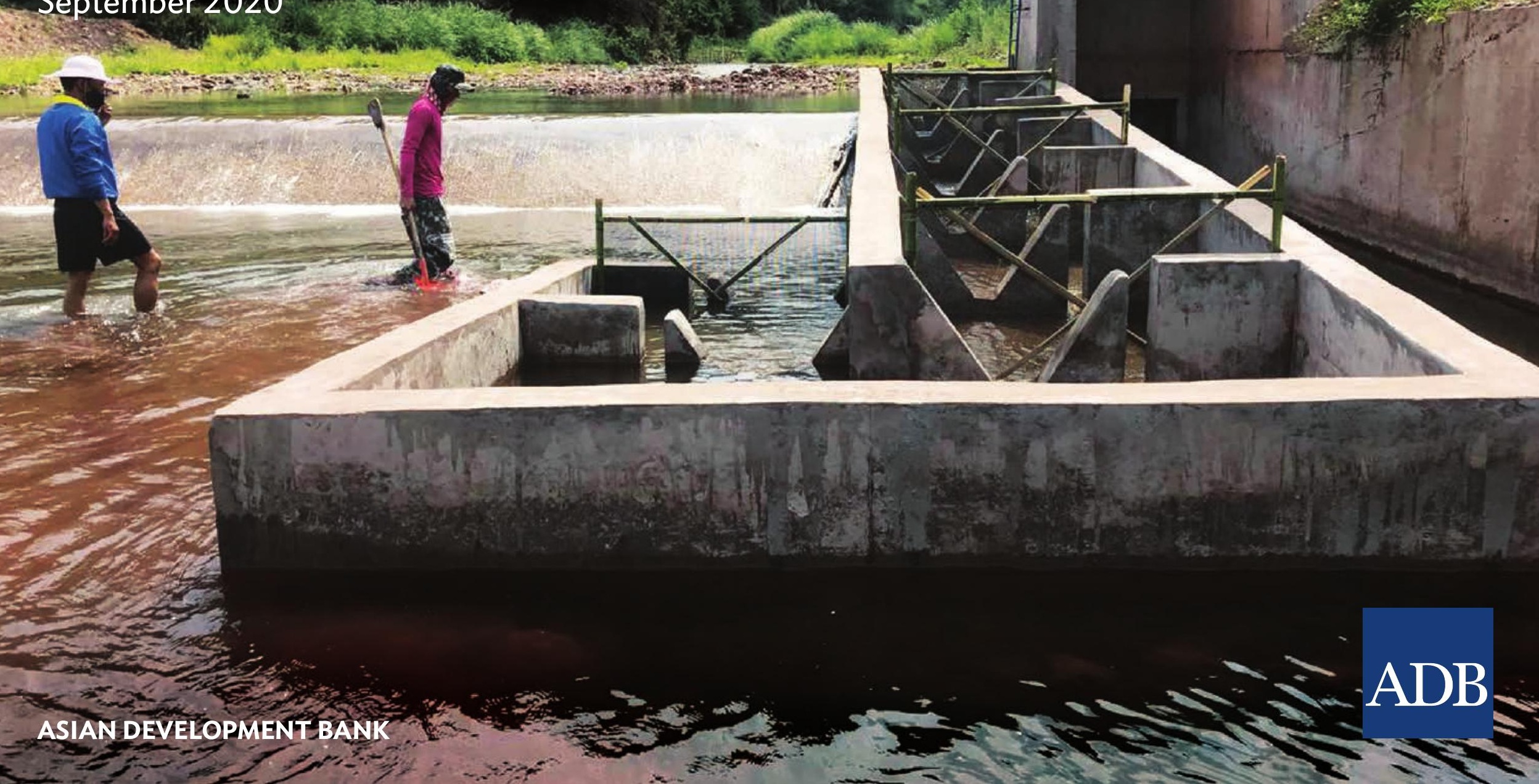




\section{DIVERSION WEIRS AND FISH PASSAGES FOR SMALL-SCALE IRRIGATION IN THE LAO PEOPLE'S DEMOCRATIC REPUBLIC}

\begin{tabular}{|c|c|c|}
\hline $\begin{array}{l}\text { David Salter } \\
\text { Principal Natural Resources } \\
\text { and Agriculture Specialist } \\
\text { Environment, Natural Resources } \\
\quad \text { and Agriculture Division } \\
\text { Southeast Asia Department } \\
\text { Asian Development Bank } \\
\\
\text { Niloofar Sadeghi } \\
\text { Water Resources Specialist } \\
\text { Environment, Natural Resources } \\
\text { and Agriculture Division } \\
\text { Southeast Asia Department } \\
\text { Asian Development Bank }\end{array}$ & $\begin{array}{l}\text { Garry Thorncraft } \\
\text { Fish Passage Research Coordinator } \\
\text { National University of Laos } \\
\text { Lee Baumgartner } \\
\text { Professor of Fisheries and River Management } \\
\text { Institute for Land Water and Society } \\
\text { Charles Sturt University }\end{array}$ & $\begin{array}{l}\text { Wayne Robinson and Nathan Ning } \\
\text { Research Fellows } \\
\text { Charles Sturt University } \\
\text { Bethany Cooper } \\
\text { Senior Research Fellow } \\
\text { University of South Australia } \\
\text { Lin Crase } \\
\text { Dean of Programs } \\
\text { University of South Australia }\end{array}$ \\
\hline
\end{tabular}


(C) 2020 Asian Development Bank

6 ADB Avenue, Mandaluyong City, 1550 Metro Manila, Philippines

Tel +6328632 4444; Fax +63286362444

www.adb.org

All rights reserved. Published in 2020.

ISBN 978-92-9262-338-8 (print), 978-92-9262-339-5 (electronic), 978-92-9262-340-1 (ebook)

Publication Stock No. ARM200210

DOI: http://dx.doi.org/10.22617/ARM200210

The views expressed in this publication are those of the authors and do not necessarily reflect the views and policies of the Asian Development Bank (ADB) or its Board of Governors or the governments they represent.

ADB does not guarantee the accuracy of the data included in this publication and accepts no responsibility for any consequence of their use. The mention of specific companies or products of manufacturers does not imply that they are endorsed or recommended by ADB

in preference to others of a similar nature that are not mentioned.

By making any designation of or reference to a particular territory or geographic area, or by using the term "country" in this document, ADB does not intend to make any judgments as to the legal or other status of any territory or area.

ADB encourages printing or copying information exclusively for personal, educational, and noncommercial use with proper acknowledgment of ADB. Users are restricted from reselling, redistributing, or creating derivative works for commercial purposes without the express, written consent of ADB. Please contact pubsmarketing@adb.org if you have questions or comments with respect to content, or if you wish to obtain copyright permission.

Corrigenda to ADB publications may be found at http://www.adb.org/publications/corrigenda.

Notes:

In this publication, "\$” refers to United States dollars.

ADB recognizes "Laos" as the Lao People's Democratic Republic.

For any technical inquiries on the content, please contact Lee Baumgartner at lbaumgartner@csu.edu.au.

On the front cover: A fish passage under construction in an ADB-financed project in Lao People's Democratic Republic (photo by Garry Thorncraft).

On the back cover: Fish passages contribute to a healthy aquatic ecosystem that underpins multiple

benefits including nutrition and food security (photo by Jim Holmes) 


\section{Contents}

Tables and Figures

A. Introduction

B. Fish, Food Security, and Irrigation

C. What Are Fish Passes and Fishways?

D. Importance of Fish Passages in ADB Operations

E. Fishway Planning and Design Processes

F. Examples of Fishway Designs and Layouts

G. Technical Description of Cost-Benefit Analysis

H. ADB Irrigation and Fishway Investments in the Lao People's Democratic Republic

a. Northern Rural Infrastructure Development Sector Project-Additional Financing

b. Retrofitting Fishways to Existing Weirs

c. Assessment of Fishway Performance

d. Results

e. General Fish Catches

I. ADB Strategy 2030

J. Conclusions 


\section{Tables and Figures}

\section{Tables}

1 Fishway Planning Process

2 Contributions of Fishways to the ADB Strategy 2030

\section{Figures}

1 Critical Linkages between Improved Fisheries and Household Nutritional Status

2 Impacts of Irrigation Infrastructure on Fisheries Productivity

3 Mapping Sample for All Fish Passage Barriers at the Xe Bang Fai Catchment in the Lao People's Democratic Republic

4 Pool and Weir Design

5 Rock-Ramp Design

6 Nature-Like Design

7 Lock Design

8 Undershot Leaf Gates and Lay Flat Fish-Friendly Gates

Various Parameters Influencing the Cost-Benefit Analysis of a Fishway Project

10 Cross-Sectional View of the Baffles at the Nam Beng Weir Fishway

11 Fish Species Caught in Nam Ben Fishway 


\section{A. Introduction}

The purpose of this paper is to provide foundational information on the importance and features of fish passages and fishways for staff of the Asian Development Bank (ADB) engaged in irrigation investments as well as their development member country (DMC) counterparts.

Fish play an important role in nutrition and income generation for rural households. According to the 2019 report by the Intergovernmental Panel on Climate Change, climate change affects fish population globally, and it has reduced maximum catch potential, leaving a significant impact on the world's diet. Moreover, overfishing and competition over scarce water resources are further stressing fish stocks. Often, development projects such as irrigation structures obstruct fish movement and reduce fish population.
ADB's operations must ensure that its infrastructure projects pose no threat to the already diminishing fish population and, ultimately, to food security.

This publication is intended to support ADB's Strategy 2030 and is based on successful experience in the application of fish passage technology in the Lao People's Democratic Republic (Lao PDR). It is not a design manual; thus, expert advice remains necessary in the actual design, construction, and operation of fish passages along with the assessment of the net ecological and economic benefits. 


\section{B. Fish, Food Security, and Irrigation}

According to WorldFish: "Globally, more than 250 million people depend directly on fisheries and aquaculture for their livelihoods." The organization says that more than 1 billion poor people receive most of their daily animal protein from fish. "The very poor often rely on fishing as a primary source of income," it adds, as many are employed in fisheries and aquaculture value chains in roles such as processing or marketing. WorldFish attributes the reduction of fish stocks to "overfishing, ineffective management practices, industrial development and agricultural pollution."

Fish population is also affected by climate change as sea temperature increases beyond the tolerating capacity of aquatic species; floods become more frequent; and there are increased risks of exposure to water diseases, parasites, and harmful algal bloom (Food and Agriculture Organization of the United Nations 2018). The 2019 report of the Intergovernmental Panel on Climate Change also finds: "In many regions, declines in the abundance of fish and shellfish stocks due to direct and indirect effects of global warming and biogeochemical changes have already contributed to reduced fisheries catches [high confidence]."

Fisheries are an important component of food security in ADB DMCs. For example, in the Lower Mekong River, inland fisheries provide food security, nutrition, and livelihoods for more than 60 million people, and buffer poverty by generating $\$ 17$ billion (Nam et al. 2015).
In the Lao PDR, the average citizen consumes 28.6 kilograms of fish per year, which is $48 \%$ of their total animal protein intake (Hortle 2007). In Myanmar, the average citizen consumes 21 kilograms of fish per year, and inland fisheries contribute $25 \%$ of the total national fisheries yield (Conallin et al. 2019). Between 40\% and 80\% of the Mekong River fish caught are species that are considered migratory (Barlow et al. 2008). Similar figures are reported in other countries such as Cambodia, Indonesia, Thailand, and Viet Nam. Figure 1 illustrates the importance of fish for food security.

As a natural phenomenon, fish regularly migrate to feed or reproduce over distances ranging from a few meters to thousands of kilometers. The creation of any barrier across a watercourse will impact both upstream and downstream fish movements, and impede growth and reproduction opportunities.

In the Lao PDR, for example, barriers have an especially negative impact as most fish species in the Lower Mekong River are migratory, seeking access to floodplains and riverine habitats during the wet season. These fish then require access to refuge areas in the dry season, and the creation of permanent deeper water in floodplains and rivers can be beneficial to both fish and the people who depend on them.

Figure 2 illustrates the irrigation infrastructure impacts on fish productivity. 


\section{Figure 1: Critical Linkages between Improved Fisheries and Household Nutritional Status}

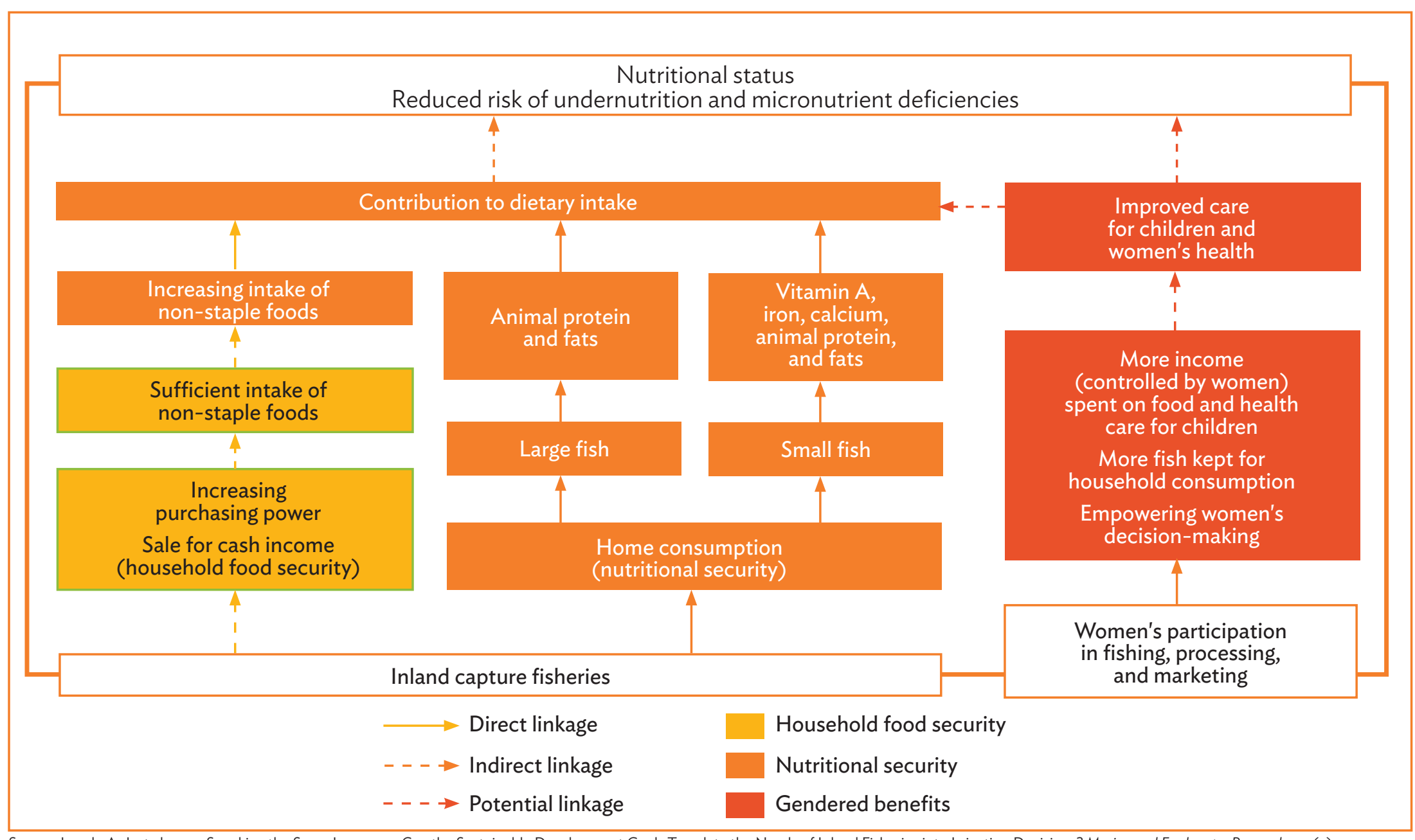

Source: Lynch, A. J. et al. 2019. Speaking the Same Language: Can the Sustainable Development Goals Translate the Needs of Inland Fisheries into Irrigation Decisions? Marine and Freshwater Research. 70 (9). pp. 1211-1228. https://www.publish.csiro.au/mf/pdf/MF19176. 


\section{Figure 2: Impacts of Irrigation Infrastructure on Fisheries Productivity}

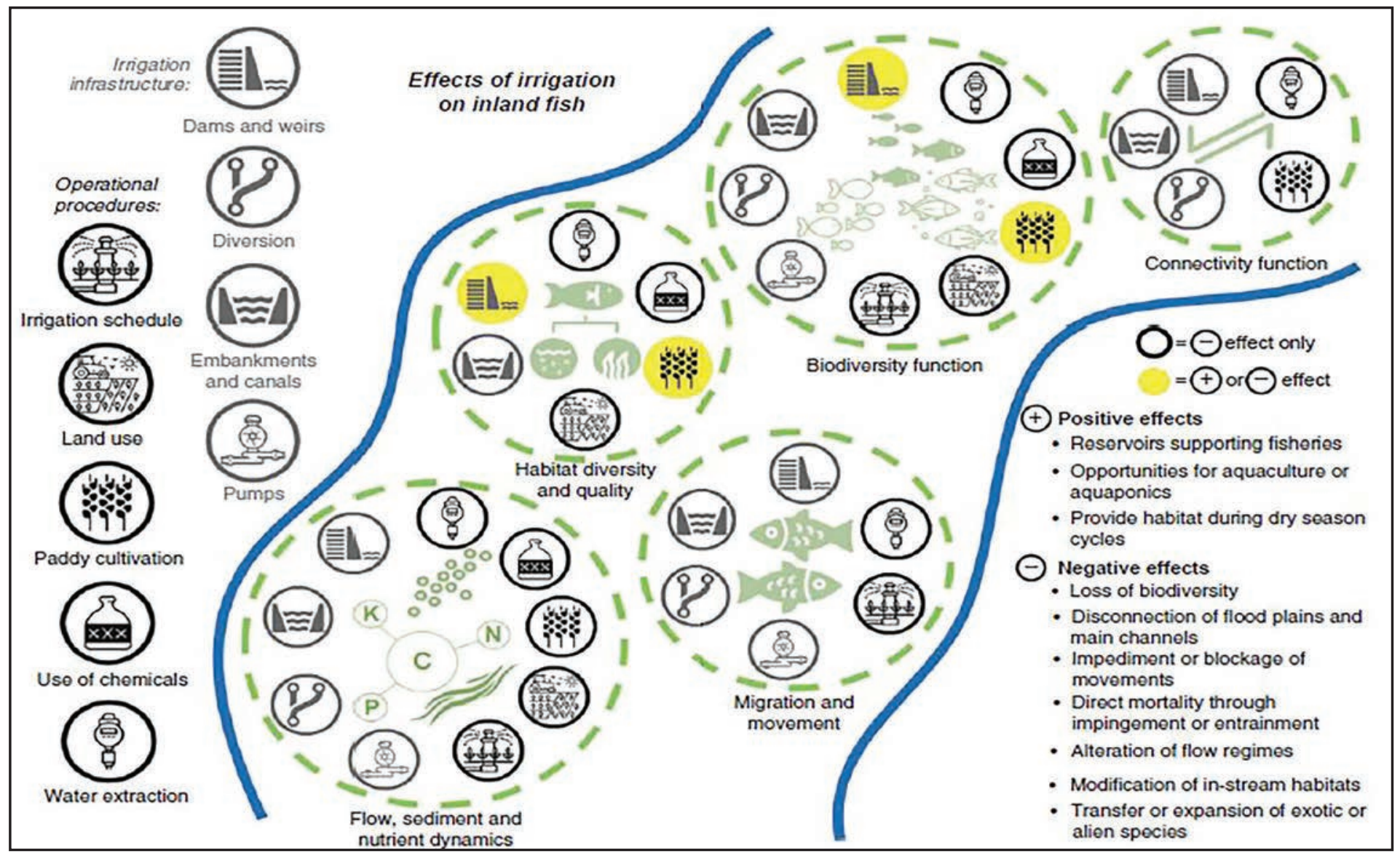

Source: Lynch, A. J. et al. 2019. Speaking the Same Language: Can the Sustainable Development Goals Translate the Needs of Inland Fisheries into Irrigation Decisions? Marine and Freshwater Research. 70 (9). pp. 1211-1228. https://www.publish.csiro.au/mf/pdf/MF19176. 
DMC governments are investing in a new wave of irrigation infrastructure and modernization to develop new systems and refurbish old ones, often with the support of multilateral development partners. Unfortunately, there is rarely the critical collaboration between irrigation and fisheries agendas, which is needed to develop workable solutions. Consequently, fishery declines are common in poor rural communities where rapid irrigation prevents access to spawning, nursery, and growth habitats. This decline is critical for four reasons:

(i) Rural communities are highly dependent on wild fish for essential nutrients.

(ii) If fisheries decline, alternative food sources must be sourced from elsewhere, reducing marginal incomes and labor resources.

(iii) Fish are an emergency food resource. When floods or natural disasters destroy rice crops, communities fall back on wild fish resources to supplement income and food security.

(iv) Species diversity is reduced and affects ecosystems, including people and other animals such as birds and reptiles. Fish passage is the term describing the directed movement of fish passing a point in a stream, which can be in an upstream or downstream direction. 


\section{What Are Fish Passes and Fishways?}

Fish passage is particularly important when considering the barrier effect of irrigation structures. Failure to address fish passage issues can lead to declining fishery stocks and negatively impact livelihoods and biodiversity. Fish passes are the technical solutions required to facilitate fish passage.

There are several types of fish passes. Fishways are the most wellknown and can be constructed into irrigation projects as structures that allow fish to pass upstream of barriers, while fish-friendly gates allow downstream movement of fish. Fishways enhance the benefits of irrigation programs. For example, fish in rice fields can help control crop parasites. Other structures that create barriers to fish migration, such as flood regulators or culverts, can also be made fish-friendly.

Different types of fishways are presented in Section F.
The risks of not considering fish passage (i.e., doing nothing) include the

(i) creation of an accumulation zone where fish are vulnerable to overfishing, disease, and injury in the early to middle wet season;

(ii) delays in fish seeking spawning habitat, potentially leading to reduced or missing annual reproduction;

(iii) delays in juvenile fish seeking feeding habitat, potentially reducing fisheries production; and

(iv) increased fish mortality due to capture in operating valves, poisoning from chemicals, as well as other agricultural practices.

These risks are cumulative across a catchment and, together, can have a severe overall impact on fisheries production. 


\section{Importance of Fish Passages in ADB Operations}

$A D B$ is investing heavily in irrigation in its DMCs. However, fishways have often been neglected in irrigation development despite being important for the following reasons:

(i) Fish are just as necessary as land crops in terms of income, livelihoods, food security, and nutrition value. Inland capture fisheries play an important role in sustainable development.

(ii) Irrigation schemes using diversion weirs or other types of obstruction can disrupt the natural migration of fish and other aquatic life, causing severe reductions in their populations.

(iii) Fishways can strengthen the resilience of aquatic life to the impacts of climate change by maintaining the natural habitat to the extent possible.

(iv) Fishways can contribute to achieving the United Nations Sustainable Development Goals (SDGs), specifically SDG 1 (No Poverty), SDG 2 (Zero Hunger), SDG 3 (Good Health and Well-Being), SDG 13 (Climate Action), and SDG 14 (Life Below Water). Inland fisheries are directly or indirectly related to almost all the SDGs.

(v) Similarly, fishways can help achieve ADB's Strategy 2030 operational priority 1 (addressing remaining poverty and reducing inequalities); operational priority 3 (tackling climate change, building climate and disaster resilience, and enhancing environmental sustainability); and operational priority 5 (promoting rural development and food security). Importantly, fishways have also shown to be capable of generating net economic benefits when these factors are taken into consideration and valued.

(vi) Development has created physical barriers that impede the natural migration of wild stocks.
Irrigation greatly benefits both rice and cash crop production. However, schemes that block streamflow have adversely impacted aquatic ecosystems and livelihoods because fish cannot access their natural spawning or nursery habitat. Thus, the benefits expected from irrigation can be partially offset by losses in fisheries productivity. The photo on p. 8 shows a weir in one of the ADB projects built in the Lao PDR in 2000.

Ideally, effective fishway construction should be mandatory in new ADB infrastructure projects. The use of engineering and management solutions to restore fish to wetland habitats through fishways has been globally demonstrated to be successful (Oldani and Baig 2002; Baumgartner et al. 2014).

Fishways installed at barriers over the entire migratory season and across multiple floodplains can rebuild fish stocks (thousands of tons of fish), improving capture fisheries and restoring biodiversity. As a result, there is a boost in job creation, economic growth, and livelihoods, which resonates with ADB's mission to eradicate poverty and foster sustainable development across Asia and the Pacific. 
Nam Ngat Weir in the Lao PDR.

The weir's headwall presents a barrier to fish migration, which can lead to reductions in fisheries yield from upstream reaches (photo by Garry Thorncraft).

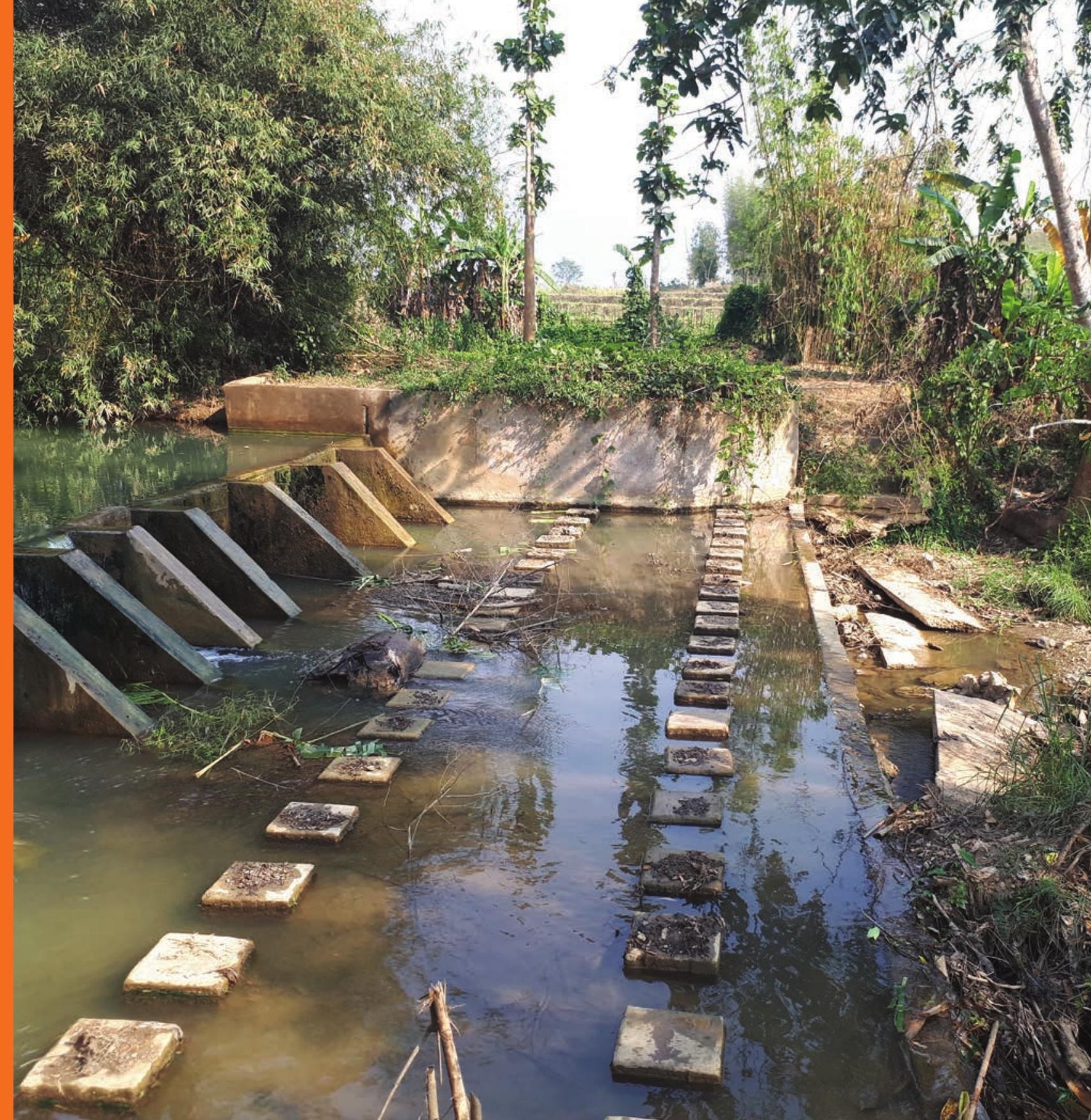




\section{E. Fishway Planning and Design Processes}

In preparing to design fishways, the first step is to identify and engage all stakeholders to work collectively to map all barriers across the catchment (Figure 3 ). The next step is to prioritize the barriers in terms of expected benefits from a fishway construction and develop a catchment-wide fishways management plan. These barriers can be "scored" against a set of metrics to determine which barriers would give the best biophysical benefit for the required investment. Table 1 presents the planning process.

Capacity development is required for experts (biologists, engineers, natural resources consultants, etc.) as well as managers who are responsible for implementing fishway programs to institutionalize fishway design and their construction as an integral part of irrigation projects.

Tailor-made courses can be designed with a focus on overcoming challenges of building upstream fishways within irrigation infrastructure.

Accredited courses or mandatory on-the-job trainings are also effective modalities to ensure key participation of target trainees.

The courses may aim to

- cover fundamental grounding of fishways, fishway ecology, and river hydrology;

- develop knowledge of target species;

- identify the location of the fishway entrance, fishway design options, cost-benefit analysis, principles of good construction, and operation and maintenance procedures; and

- monitor the effectiveness of a fishway.
In ADB-financed Sustainable Rural Infrastructure and Watershed Management Sector Project in the Lao PDR, which was approved in September 2019.

This work will include a "master class" in fish passage design. 
Figure 3: Mapping Sample for All Fish Passage Barriers at the Xe Bang Fai Catchment in the Lao People's Democratic Republic

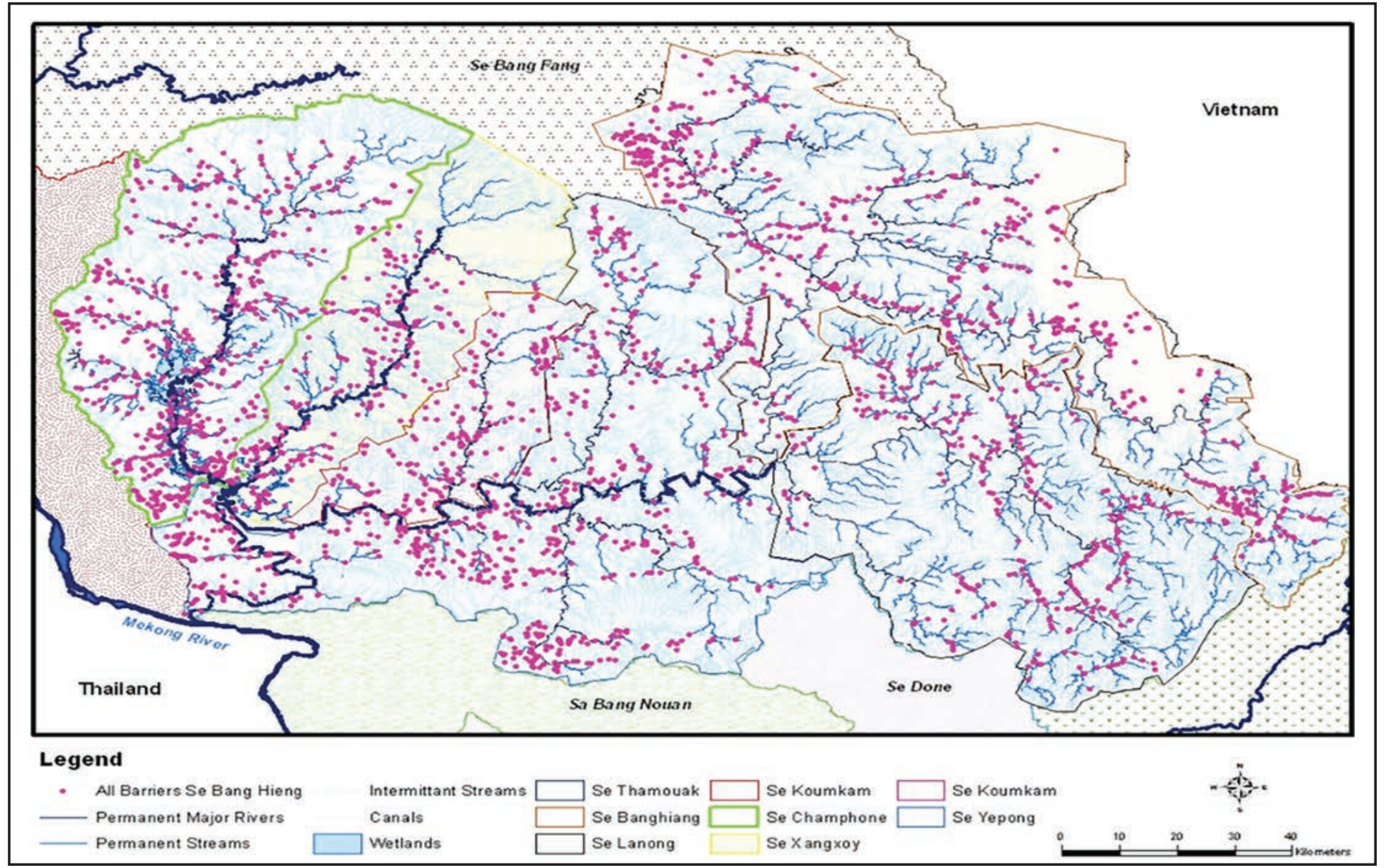

Source: Baumgartner, L. et al. 2016. Development of Fish Passage Technology to Increase Fisheries Production on Floodplains in the Lower Mekong Basin. Australian Centre for International Agricultural Research. Canberra. 


\section{Table 1: Fishway Planning Process}

\begin{tabular}{|c|c|c|}
\hline Step & Action & Discussion \\
\hline 1 & Map all barriers in each catchment. & $\begin{array}{l}\text { This action considers the cumulative impact of barriers and enables the } \\
\text { development of a priority list of barriers where providing a fishway would create } \\
\text { the most positive impact. }\end{array}$ \\
\hline 2 & $\begin{array}{l}\text { Carry out a cost-benefit analysis of } \\
\text { building a fishway. }\end{array}$ & $\begin{array}{l}\text { If market value of the benefits of a fishway outweighs the cost, the construction } \\
\text { is supported. If costs outstrip market gains, different scenarios are tested } \\
\text { to establish if other nonmarket gains warrant construction (e.g., in terms of } \\
\text { increased nutrition, increased fisheries yield, or both). }\end{array}$ \\
\hline 3 & $\begin{array}{l}\text { Develop plans for fishways at each } \\
\text { barrier in the waterway. }\end{array}$ & $\begin{array}{l}\text { Each barrier design should include contingency plans for a fishway so that even } \\
\text { if the barrier is not built at the initial stage, it can accommodate an upgrade. A } \\
\text { series of masterclass workshops are used to generate capacity to undertake this } \\
\text { work efficiently. }\end{array}$ \\
\hline 4 & $\begin{array}{l}\text { Provide for a fishway, for lower-priority } \\
\text { barriers, to be retrofitted at a later stage. }\end{array}$ & $\begin{array}{l}\text { For lower-priority barriers, for which there are not enough funds, draft a concept } \\
\text { design for a fishway to be retrofitted at a later stage. }\end{array}$ \\
\hline
\end{tabular}

Source: Thornraft, G. et al. 2019. Fishway Options and Performance: Northern Rural Infrastructure Project. National University of Laos / Charles Sturt University. 


\section{F. Examples of Fishway Designs and Layouts}

There are several considerations in the design of fishways. The irrigation channel's depth, width, slope, water velocity, and fish species are a few of the factors that impact the design of fishways. Other nonmeasurable factors, such as the channel's waterhead during different hours of the day, especially during afternoons, can be critical in the efficient performance of fishways. Fishways should ideally form part of irrigation system design from concept to commissioning but can also, if necessary, be retrofitted to existing schemes.

However, the application and suitability of different designs need to be tailored according to the local conditions and fish species. These considerations impact both costs and benefits and are discussed later in this paper. Despite different design options, a fishway is a simple structure that facilitates the movement of fish in the opposite direction of the channel's flow. Removal of an obstacle is always the first solution to get the best outcomes for fish movement (Bednarek 2001).

Generally, fishways need to be constructed close to the weir crest. Because fish will swim upstream as far as they can, then laterally seek a way past the barrier, entrances downstream of the crest will only attract a tiny percentage of fish into the fishway. If fish cannot locate the entrance, they will not ascend to the fishway. This is a critical design parameter that cannot be compromised.

The fishway is comprised of a series of drops and baffles followed by pools to dissipate water velocity and turbulence so that fish can make short bursts of movements through each baffle, and then recover and move up to the next baffle.
Fishways should be below crest levels and downstream tailwater levels to provide a minimum depth of water for fish to ascend. Ideally, the channel walls will be high enough to prevent overtopping when the river levels rise and the entrance of the fishway has sufficient depth of water for low flows.

Fishway exits need to be away from high-flow areas so that fish exiting the fishway are not at risk of being immediately swept back downstream over the crest.

Pool and weir design. Generally, this fishway consists of concrete channels divided by baffles to control the velocity and turbulence of water (Figure 4). The channel slope, cell size, and baffles size and spacing are determined based on local fish species.

Rock-ramp design and layout. The design and the layout can be full or partial width across the weir with rock ridges placed to control the velocity and turbulence of water flowing down the channel rock size and to remain stable in high flows up to weir drown-out levels (Figure 5).

Nature-like design and layout. This design is built outside the stream channel on low gradients with large pools and small drops (Figure 6). It is generally suitable only for small barriers with low headwater ranges, otherwise higher structures require a very long channel.

Lock design and layout. This design is suitable for structures above 6 meters in height when it is not feasible for fish to swim up very long channel-type fishways (Figure 7). High operation and maintenance costs are expected. 
Figure 4: Pool and Weir Design

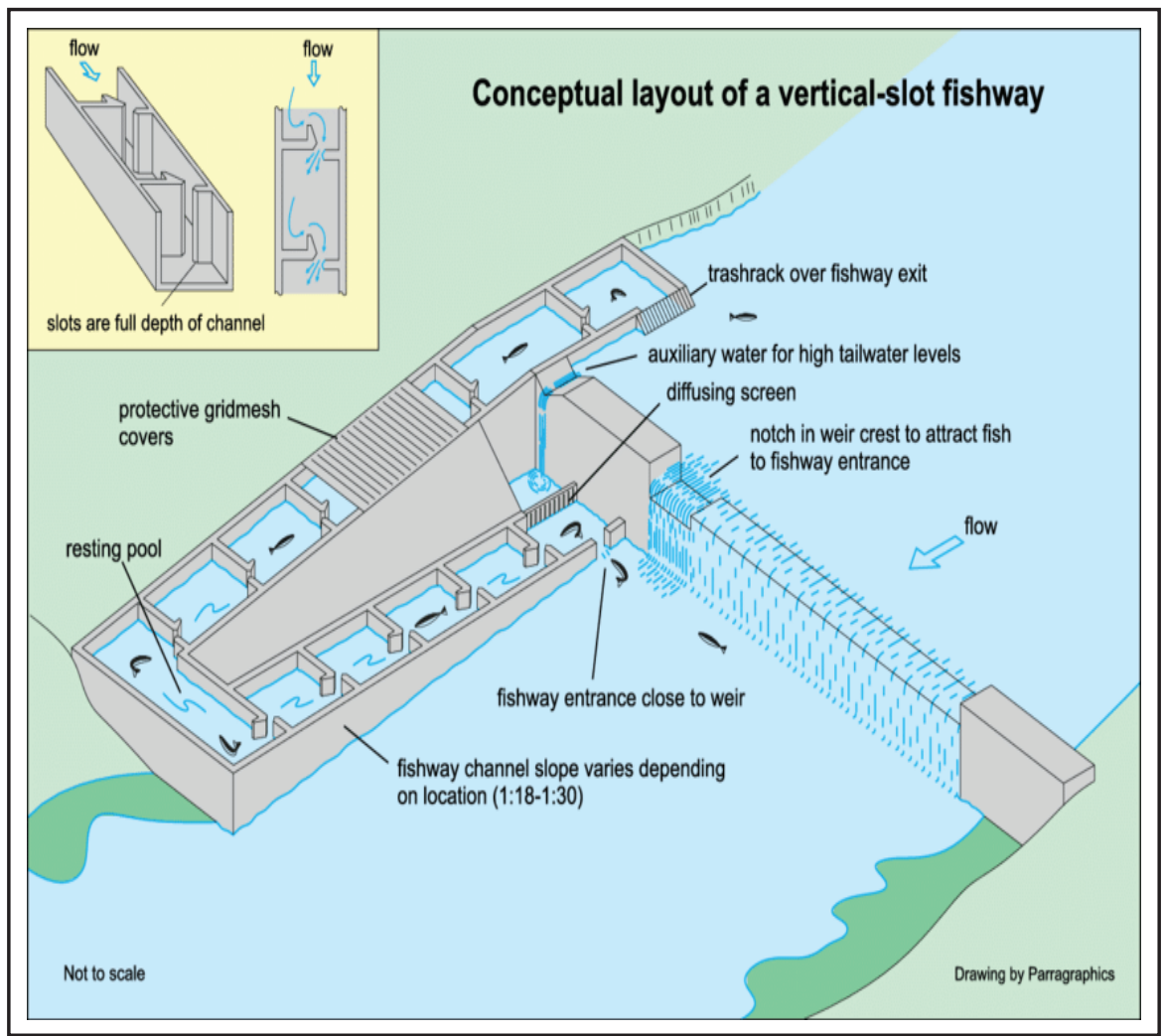

Source: Thorncraft, G., and J. H. Harris. 2000. Fish Passage and Fishways in New South Wales: A Status Report. Cooperative Research Centre for Freshwater Ecology Technical Report. 1/2000. Canberra,

Australia. https://pdfs.semanticscholar.org/8812/005625egd639ae8aa91dbf1f877a335f5aod.pdf?

-ga=2.36172064.1694021025.1587109440-1571659318.1587109440.
Figure 5: Rock-Ramp Design

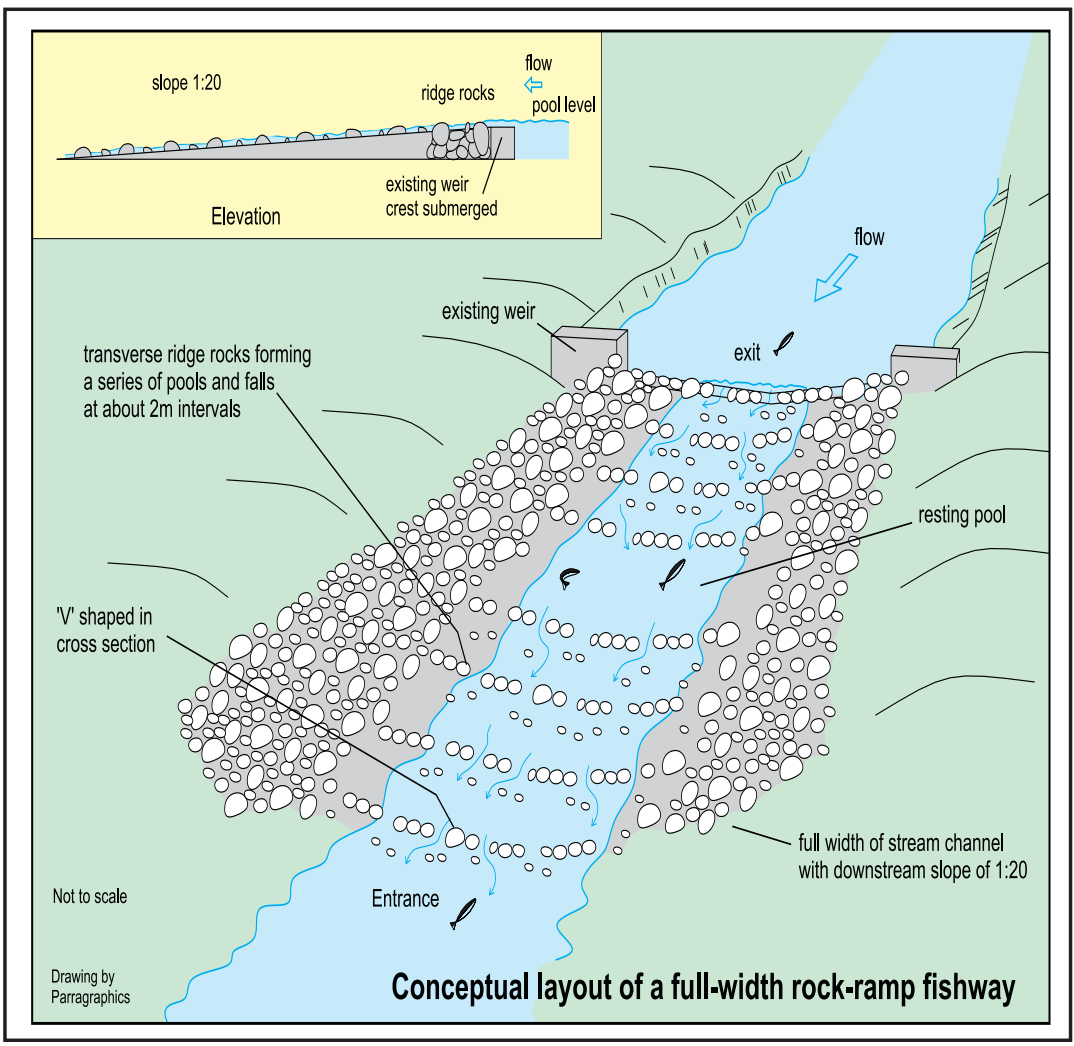

Source: Thorncraft, G., and J. H. Harris. 2000. Fish Passage and Fishways in New South Wales: A Status Report. Cooperative Research Centre for Freshwater Ecology Technical Report. 1/2000. Canberra, Australia. 
Rock-ramp layout. A partial width design with ridge rocks used to simulate a natural stream (photo by Lee Baumgartner).

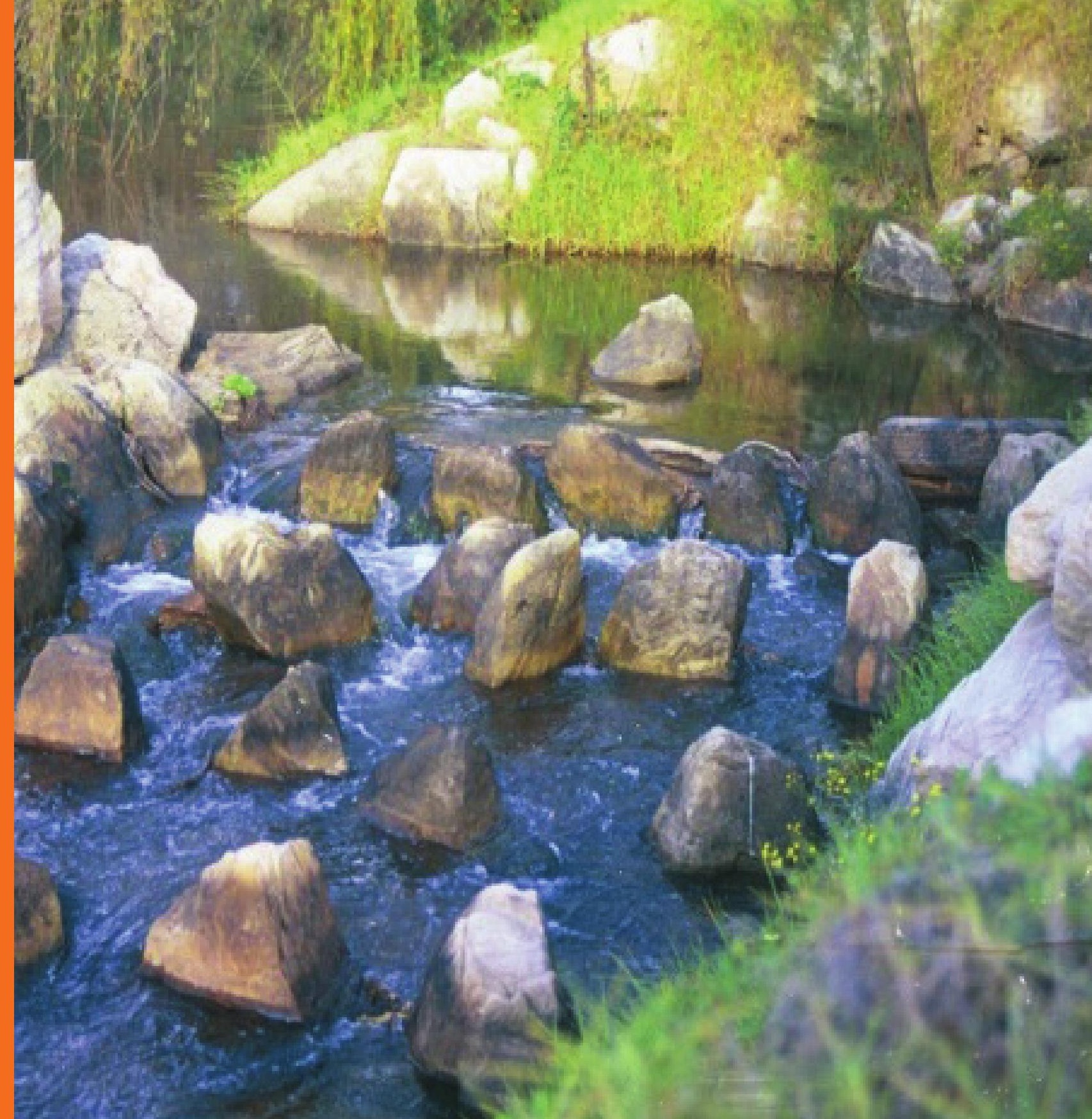


Figure 6: Nature-Like Design

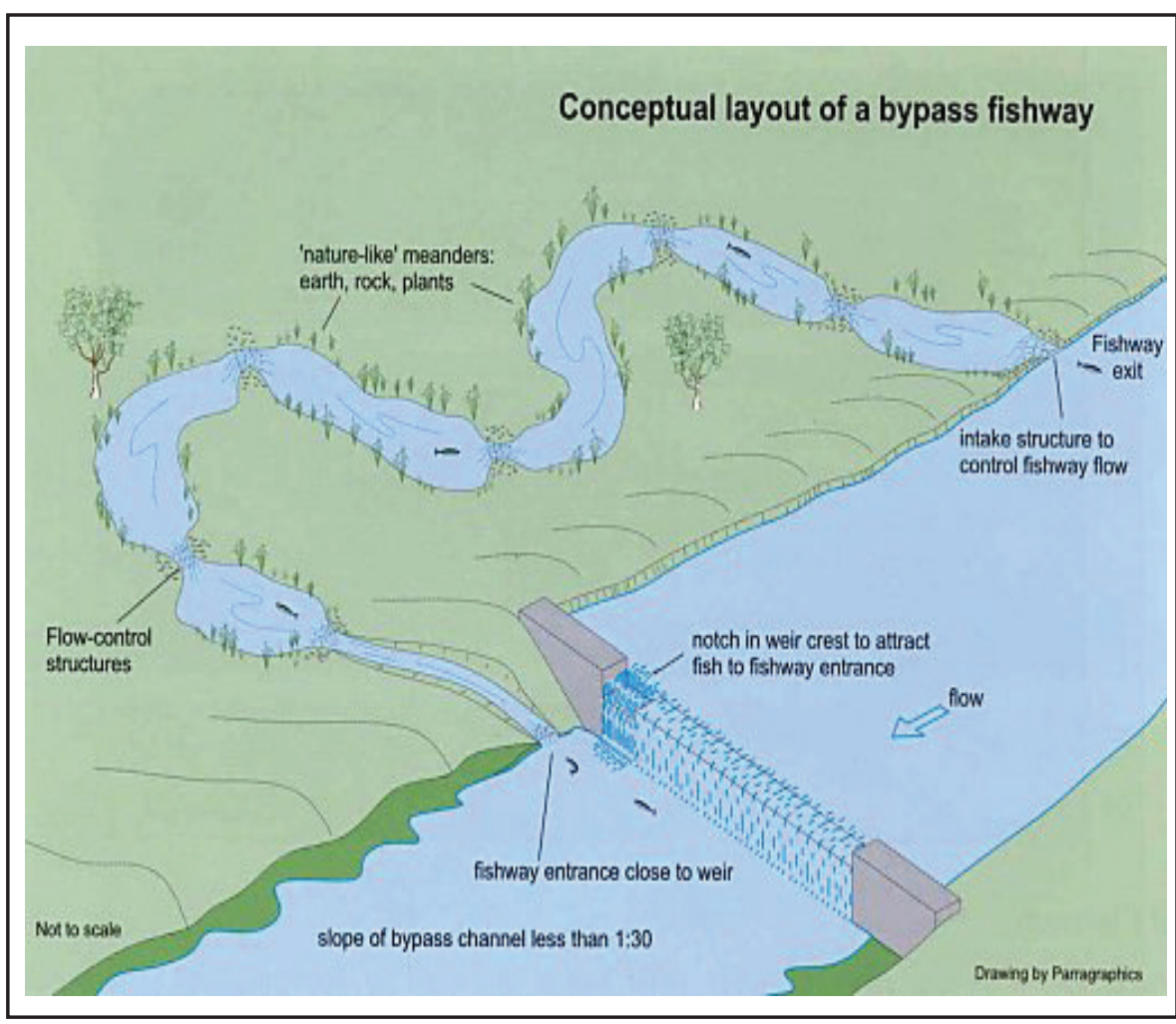

Source: Thorncraft G., and J. H. Harris. 2000. Fish Passage and Fishways in New South Wales: A Status Report. Cooperative Research Centre for Freshwater Ecology Technical Report. 1/2000. Canberra, Australia.

\section{Figure 7: Lock Design}

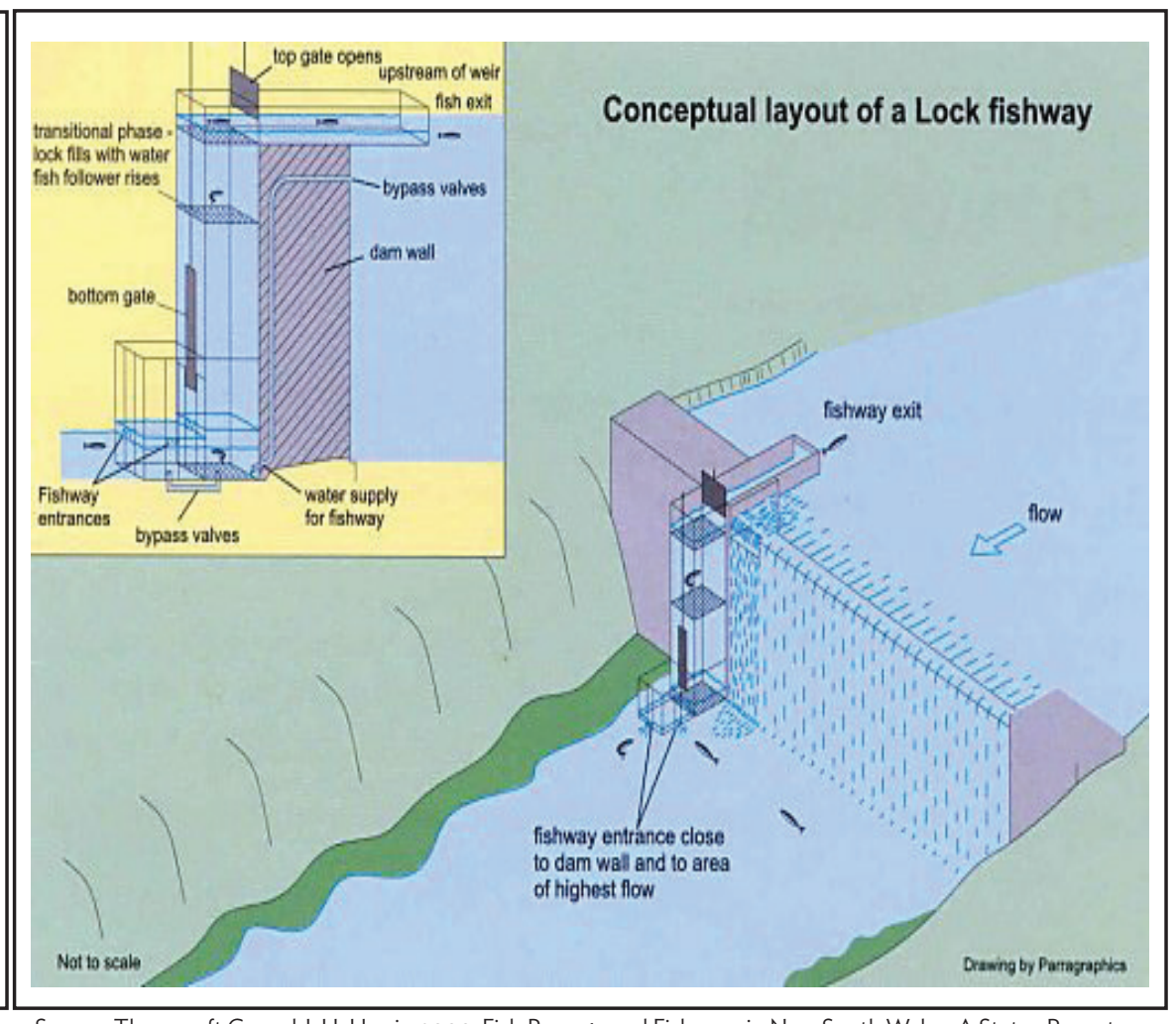

Source: Thorncraft G., and J. H. Harris. 2000. Fish Passage and Fishways in New South Wales: A Status Report. Cooperative Research Centre for Freshwater Ecology Technical Report. 1/2000. Canberra, Australia. 
Nature-like layout. The fishway at Thiensville Dam on Milwaukee River in Ozaukee County, Wisconsin is designed to mimic a natural channel (photo by Wisconsin Department of Natural Resources).

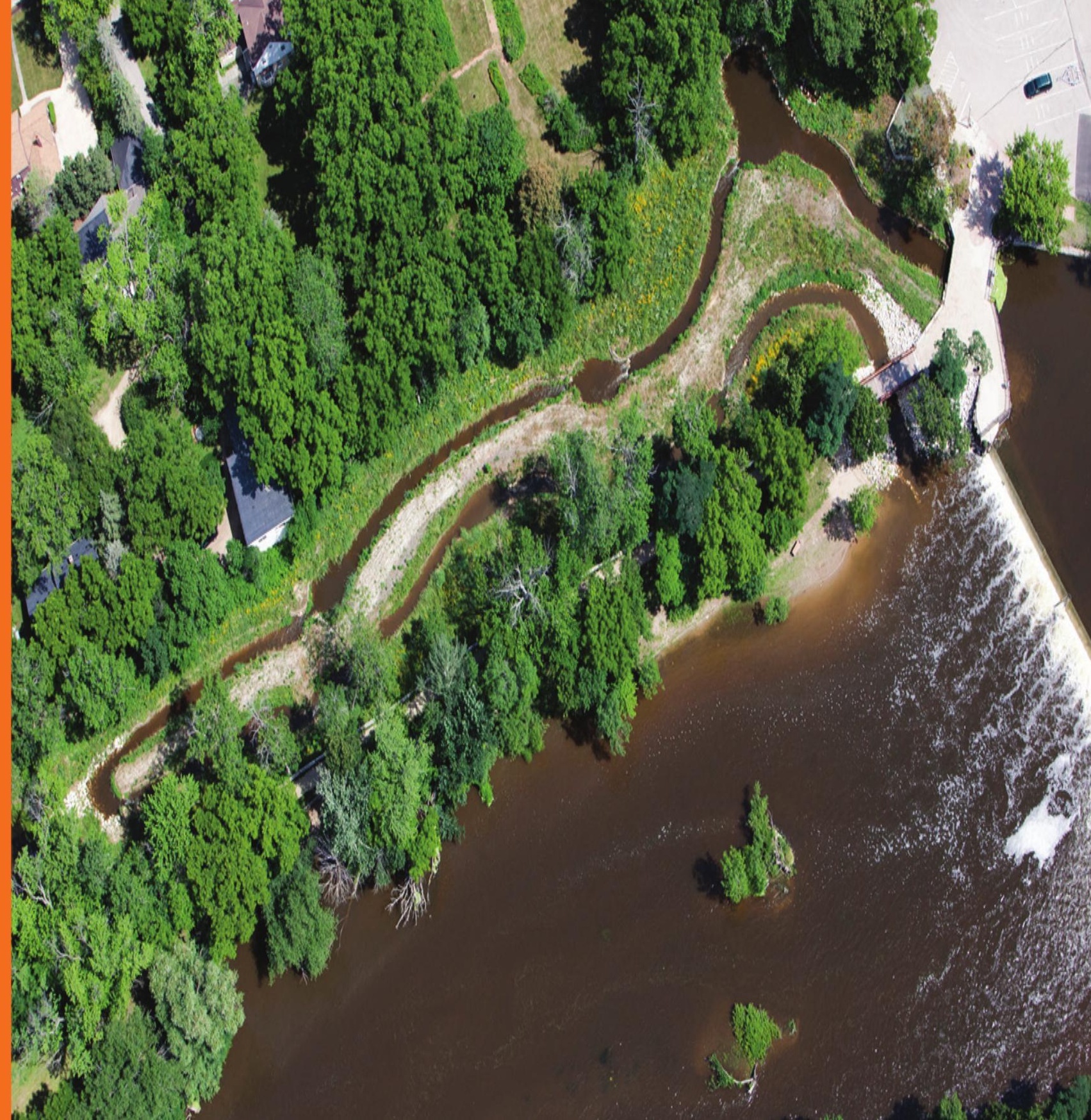


Lock layout. This is a modified version of a Deelder lock, with multiple entrances, to cater for high and low tailwater. (photo by Lee Baumgartner).

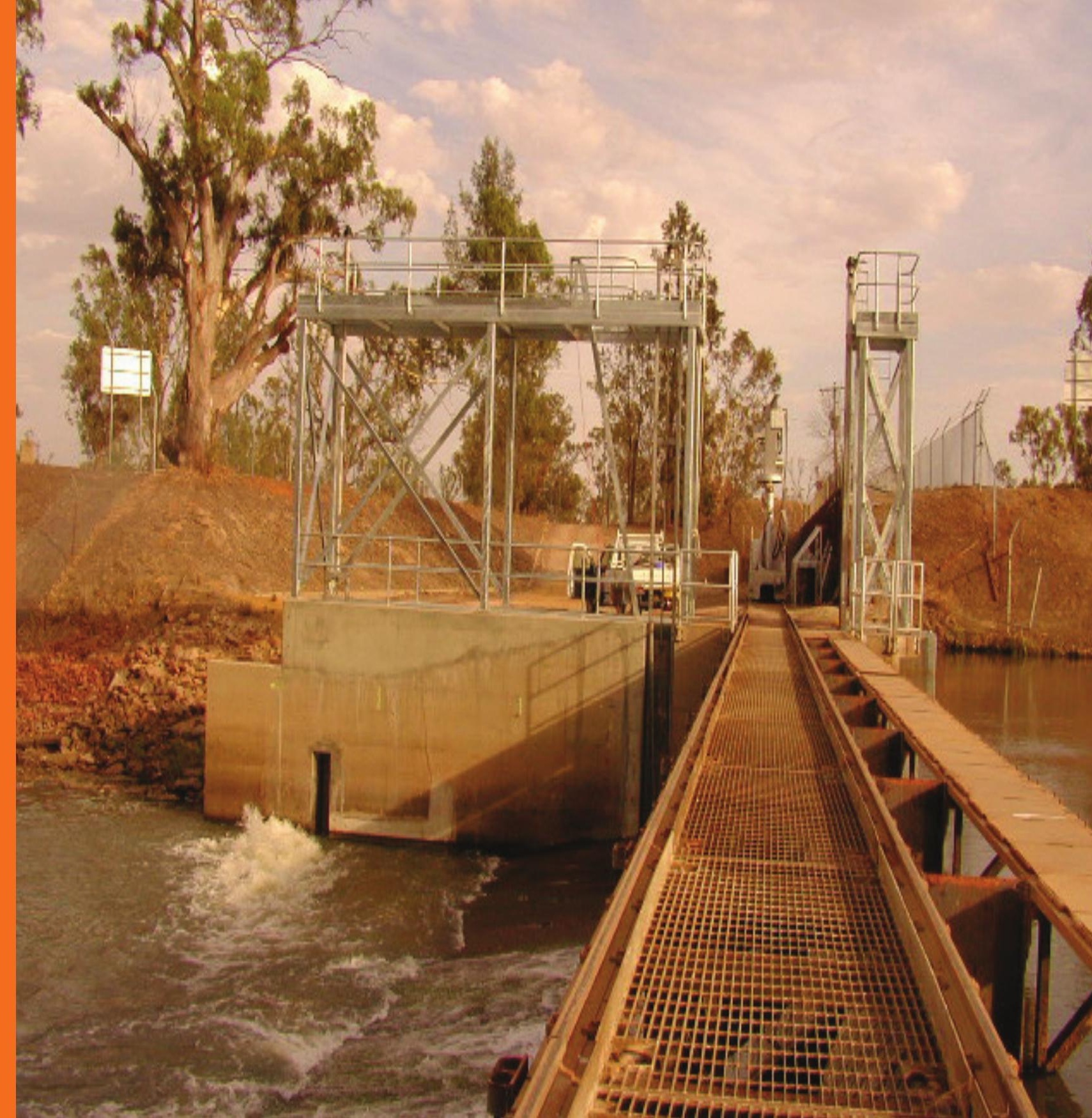


Cone layout. The cone fishway (p. 19) is built around existing floodgate, done to avoid destabilizing old weirs by using the original watercourse and installing a new culvert away from the weir to connect to the wetland. This type was used in the Pak Peung Fishway in Paksan, Lao PDR and proved to be effective.

Fish-friendly culverted bridges and weir floodgates. Modifying the apron on existing culverted bridges and floodgates allows fish access to the culverts and backwaters, enabling passage through low flows until the upstream water level exceeds the roof of the culvert. This often means that dedicated water management plans are needed to keep headwaters low during fish migration periods and ensure that any upstream or downstream gates are fully open.

Fish-friendly downstream passage gates. Figure 8 illustrates the design concept as to how lay flat gates were installed just upstream of the existing leaf gates at Pak Peung experimental site in the Lao PDR. Safe downstream passage of fish was tested through the lay flats when in operation. When completely lowered, passage was assessed through the lay flat gates and compared with passage through standard undershot leaf gates.
The assessment determined that undershot leaf gates that open from the bottom first create large pressure changes and high velocities that can kill and injure fish passing downstream.

The lay flat gates, with a deep downstream plunge pool, allowed for the safe passage of fish as it greatly reduced pressure and flow. These gates can be retrofitted directly to the upstream sides of culverts and drastically reduce the labor required to operate them compared with commonly used leaf gates.

Most importantly, these gates improve the survival of downstream migrating fish. 
Cone fishway. This is the first fishway constructed exclusively for Lower Mekong River species in the Lao PDR (photo by Garry Thorncraft).

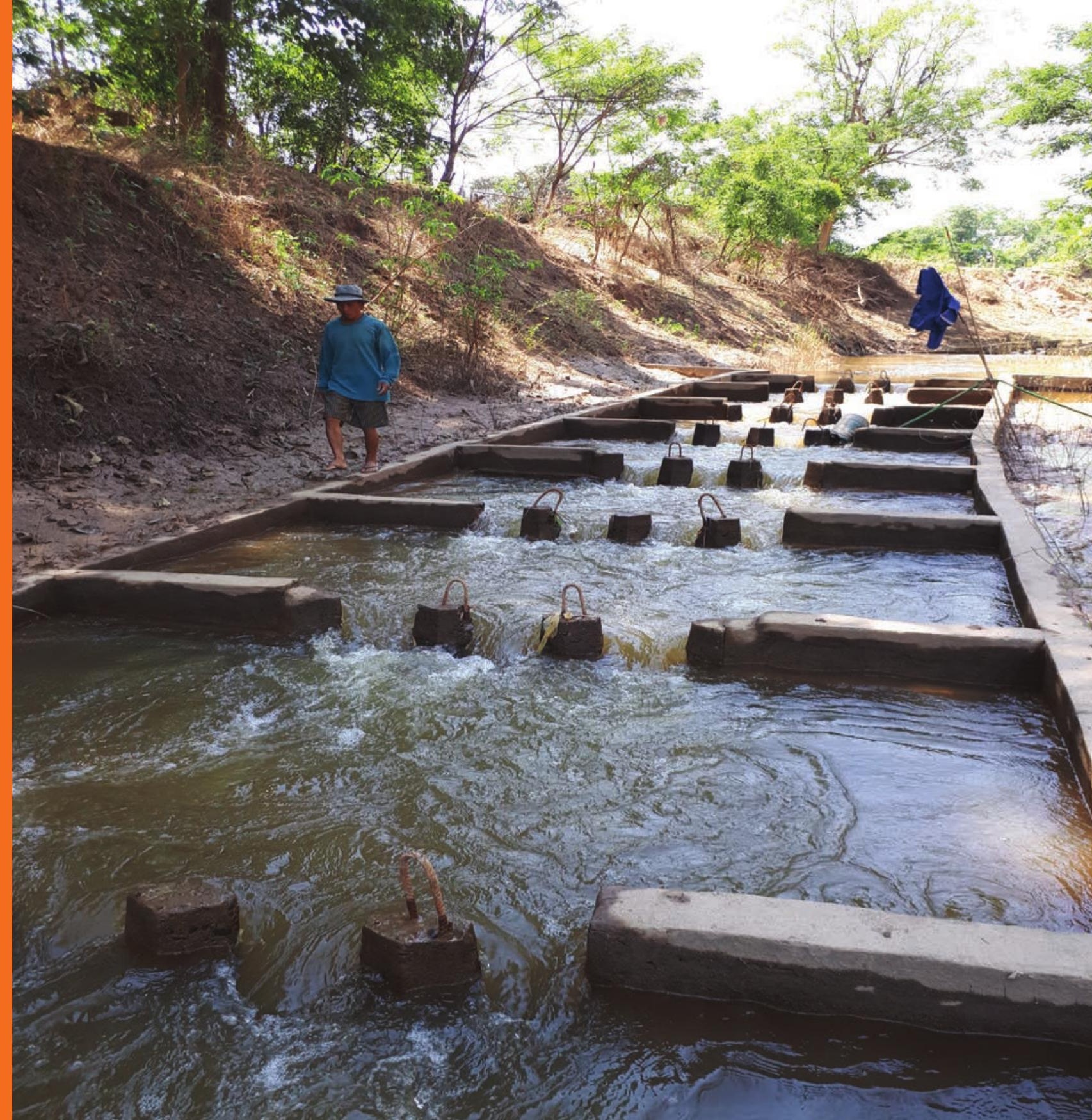


Fish-friendly culverted bridges and weir floodgates. This has a fish-friendly device leading up to a flap gate through a road crossing (photo by Lauren Withers).

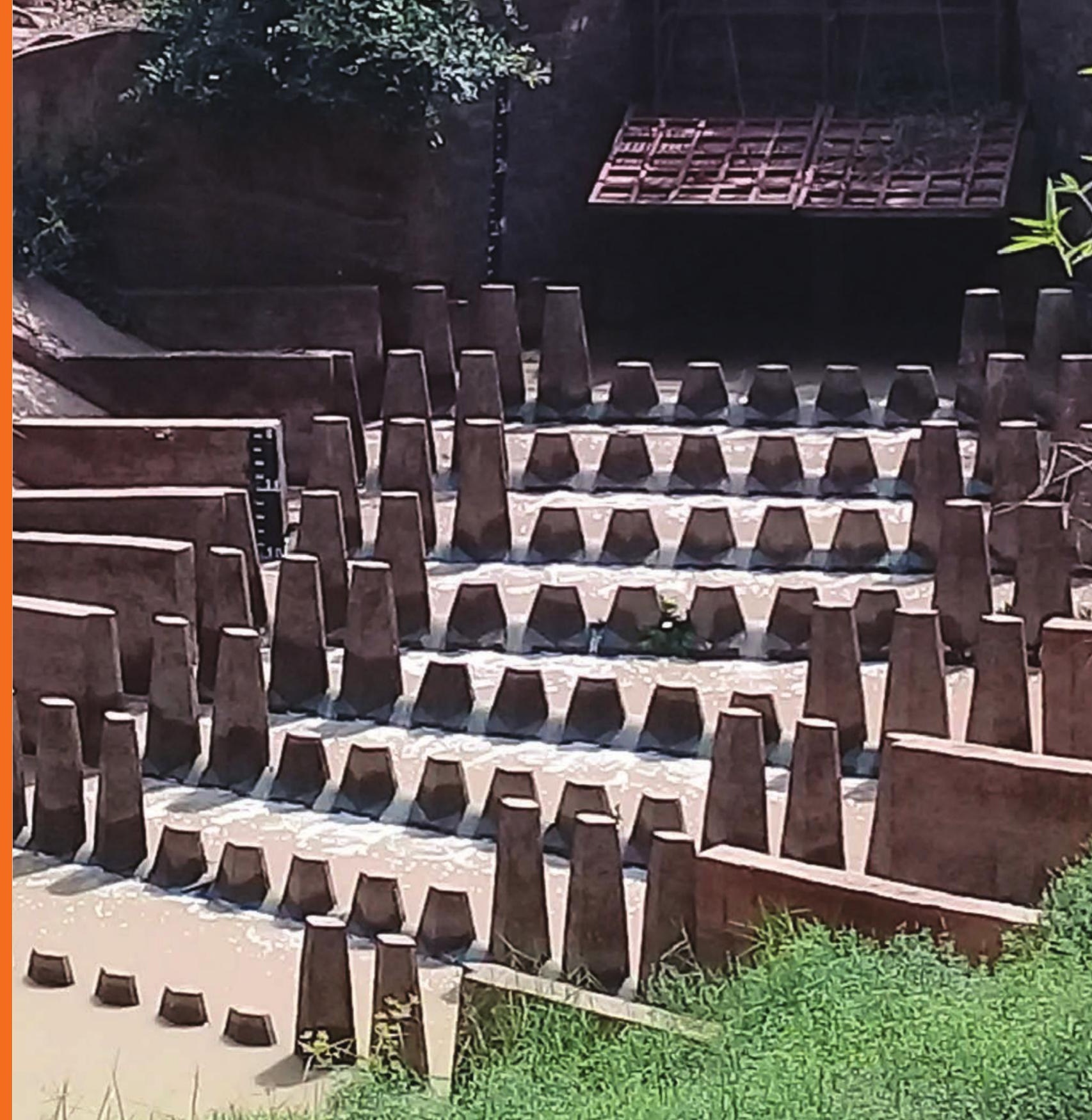




\section{Figure 8: Undershot Leaf Gates and Lay Flat Fish-Friendly Gates}

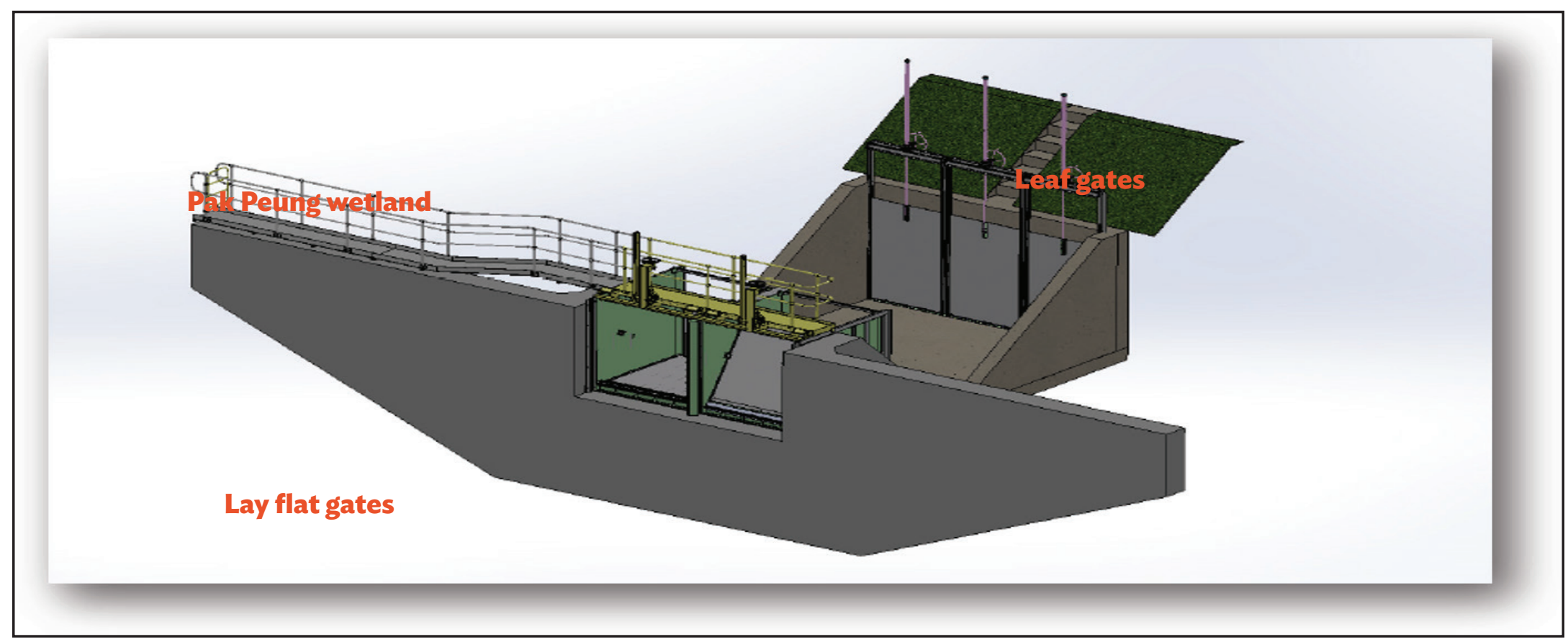

Source: Craig Boys. The gates allow water to flow over the top of the barrier rather than beneath the gate. Water flowing under the gate can lead to high fish mortality. The gate designs can reduce mortality to below $5 \%$. 


\section{G. Technical Description of Cost-Benefit Analysis}

Cost-benefit analysis is an approach that systematically clarifies the economic impacts of a project. It does not deliver the immutable best answer, but it tries to inform the decision-maker about the possible consequences of different choices, to the extent that they can be measured in monetary terms.

There are four steps for cost-benefit analysis:

(i) establishing the scope of costs and benefits;

(ii) measuring each cost and benefit in dollar terms, if possible;

(iii) applying a discount rate to any future costs or benefits such that they can be compared in terms of present values; and

(iv) executing a decision rule, such as supporting the option that has the greatest net benefit or the project with the highest and positive benefit-cost ratio.

In the context of fishways in the Lower Mekong River, an explanation is provided below about the development of the Lower Mekong Fishway Support Tool (LMFST) against the four basic steps of costbenefit analysis. The relationship between parameters is illustrated in Figure 9.

Scope. Fishways can generate ecosystem services that span the length of the Mekong River and its tributaries. In addition, they can preserve native species, creating value for future generations as well as livelihood and food security benefits (Baker and Ruting 2014). However, to keep the LMFST tractable, benefits and costs are limited to those in the immediate region of the fishway and/or those directly and materially related to its construction. Thus, the LMFST is calibrated to indicate localized benefits and costs only.
Financial value of benefits and costs. In the LMFST, emphasis is placed on generating values in financial terms that are consistent with the goals of investors. Cost parameters are mostly monetized for the region and tested with the experiences of actual construction at field sites where fish passages had been previously constructed. Estimates of fishway construction costs are generally unavailable. Actual costs are usually tied to the funds available rather than the estimated cost of building and operating a fishway from first principles.

The user of the LMFST can select (i) a fishway construction type, (ii) the distance from the source of inputs, (iii) the likely height of the structure, (iv) the requirement for upstream and downstream passage, and ( $v$ ) the necessity of extensive or minimal site works. These data automatically generate an approximate construction cost. The maintenance costs are estimated as a percentage of construction.

Benefits are calculated as accrued income from the direct selling of fish or the nutritional value it brings to farmer households over the lifetime of the irrigation infrastructure. The monetary values of benefits are considered strictly as the first round of income from marginal gains in fish production. In simple terms, the fishway is expected to generate an ecological response in the form of additional fish biomass to the receiving waterbody. The market value of this additional fish biomass is then presumed to capture the local benefits. The data to accomplish this are a mix of secondary sources and recently collected primary data to establish the range of likely impacts. These data are being improved to reflect seasonal 


\section{Figure 9: Various Parameters Influencing the Cost-Benefit Analysis of a Fishway Project}

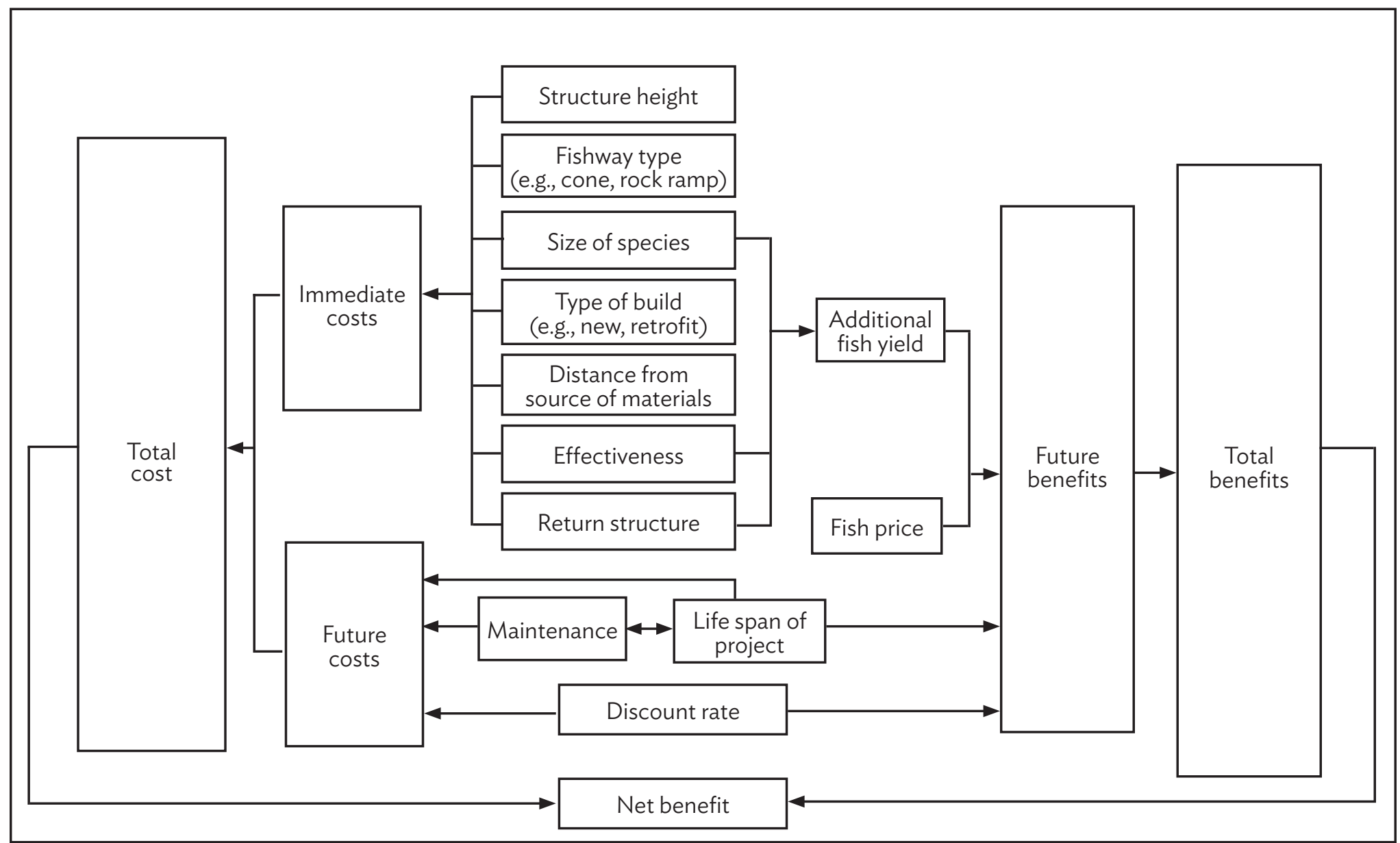

Source: Cooper B., L. Crase, and L. J. Baumgartner. 2019. Estimating Benefits and Costs: A Case of Fish Passages in Lao PDR and the Development of the Lower Mekong Fishway Support Tool. Marine and Freshwater Research. 70 (9). pp. 1284-1294. https://www.publish.csiro.au/mf/MF19156. 
and environmental changes as new versions of the LMFST are being developed.

Discounting. Discounting provides a means of comparing future benefits and costs with current benefits and costs. In many projects, including fishways, the construction costs are carried at the commencement of a project, while benefits arise in the form of a stream of returns over time. Some costs might accrue over time also, such as maintenance and repairs.

The designer decides on the expected life of the fishway structure. Only in very rare circumstances will a dollar to be received in the future hold an equivalent value to a dollar earned now. The LMFST allows the user to select multiple discount rates (0\%-20\%) and assists the user with sensitivity analysis.

Decision ruling. The LMFST produces multiple outcomes. It informs the decision-maker and provides a simple mechanism for testing and improving understanding of the impacts of different factors on the efficacy of a fishway. The information generated by the LMFST includes the net present value of a particular fishway, the benefit-cost ratio, and the payoff period for the investment. The impacts in terms of nutrition are also generated to help inform potential business cases, recognizing that the LMFST deals only with monetized and local values and the fact that many poor regions of the Mekong River are dependent on fish for consumption.

The decision support tool itself can be applied to any development project with a range of different parameters. As it stands, the LMFST is simple and straightforward to apply and is currently undergoing refinement to account for a range of additional complexities, including interruptions due to climate change and other impacts on market prices as fish stocks change in the region.

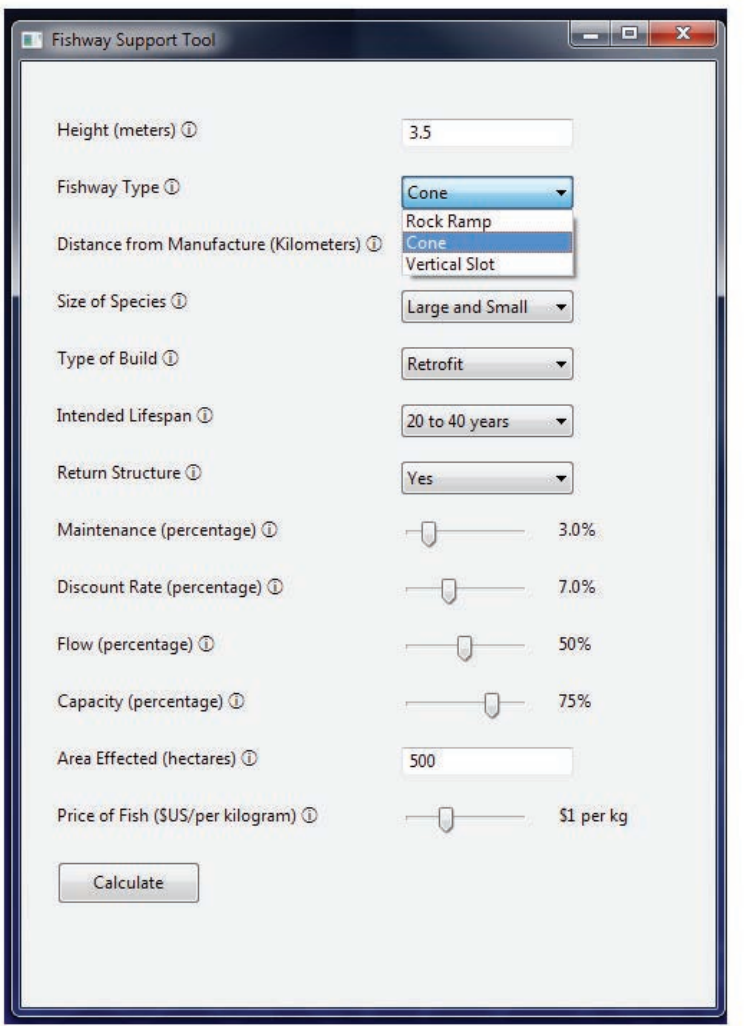

Screenshot of fishway support tool for development projects. This is a sample input screen for the Lower Mekong River Basin Fishway Support Tool MK1 (photo from B. Cooper, L. Crase, and L. J. Baumgartner 2019). 


\section{H. ADB Irrigation and Fishway Investments in the Lao People's Democratic Republic}

The overarching strategy for fishway research is adaptive management. Adaptive management recognizes that research is required to generate knowledge and that knowledge is used to build institutional and individual capacity, which is then translated into governance, policy, and practice. In strong adaptive management frameworks, research informs the development agenda that adaptively changes as new knowledge is generated. Without robust data, it is impossible to make sound development decisions. These data are also needed to inform improvements in the development of the various support currently available to decision makers.

\section{a. Northern Rural Infrastructure Development Sector Project-Additional Financing}

National design engineers from the Northern Rural Infrastructure Development Sector Project-Additional Financing (NRI-AF) worked with fishery experts from the National University of Laos and Charles Sturt University (hereinafter referred to as the team). The team visited 16 sites, which were (i) new structures built by the project based on similar designs, (ii) non-project structures with formal engineering design elements, and (iii) weirs constructed by villages with informal designs that have been built up over time. Both project and non-project sites were visited, including those situated downstream and outside of the project area that limit fish passage to project sites.

During the site inspections, the condition of the streams was generally degraded, with extremely high levels of fine and coarse bed load, and with a near-total loss of weir pool volume due to sedimentation. Sedimentation has serious implications for designing fishways for these structures, as the pool and baffles can suffer maintenance issues under these conditions.

\section{b. Retrofitting Fishways to Existing Weirs}

At four NRI-AF subproject irrigation schemes (Nam Beng, Houay Lor, Nam Met, and Nam Oun) diversion, weirs were constructed with inadequately designed fishways passages, requiring mitigating measures. The fishways originally built by the project had no proper design and were not performing their "fish passing" functions, hence the need to adopt new designs.

The team developed low-cost designs and monitoring measures to minimize the impacts of the weirs on fish populations. A modified trapezoidal fishway was used to retrofit two of the four NRI-AF fishways.

Weir design and condition have implications on the potential retrofit of fishways to these structures. Retrofitting fishways to weirs would require major alterations to the weir structures with these implications:

(i) The fishway's footprint can either be placed within the streambed or built into an adjacent streambed. Those built within the stream may reduce discharge capacity as a portion of the crest is blocked, potentially resulting in increased upstream flooding or, if within the bank, requiring land acquisition. 
(ii) A notch needs to be cut through the weir crest, or the side abutments and walls of the weir if the fishway is within the stream bank, to provide the correct entrance locations and flows conditions within it.

A modified trapezoidal fishway used previously in Australia (to fit within the available fishway footprint) was recommended as an experimental approach to retrofitting two of the existing four project-built fishways for the following reasons:

(i) The design features a high-volume section of channel that is expected to help flush sediment through the fishway and reduce the need to clear the channel of sand and rock after each flood event.

(ii) The high-volume section provides additional attraction to the fishway entrance at higher tailwater levels when the flow from the vertical slot is back flooded.

(iii) The design allows a full-depth vertical slot to be incorporated, which provides passage for bottom- and surface-moving fish.

(iv) As the vertical slot is adjacent to the high-volume section, it greatly reduces the risk of children being caught in the slot and the cells suddenly overtopping, which is a drowning risk for small children.

(v) As the chosen design is experimental, only the two lowerheight barriers are to be retrofitted, while the decision to retrofit the two higher-height barriers is put on hold.
A notch in the weir crest is cut on the left side of the crest (right side of photo) to allow water into the fishway so that it would operate at a minimum depth. To ensure that the fishway entrance is constructed close to the weir channel and accessible to the fish, the team builds it with a 180-degree turn that leads back upstream to ensure that the fishway entrance is close to the base of the weir, where fish migrating upstream will congregate. The height of the walls of the channel should be enough so that the fishway is still operational as the weir itself drowns out at high flows. Drowning out is where there is no difference in water levels upstream and downstream of the structure.

\section{c. Assessment of Fishway Performance}

Study site. A preliminary assessment was undertaken at the Nam Beng fishway to determine performance within design specifications in terms of both hydraulics (flow of water through the structure) and biology (actual movement of fish). The Nam Beng fishway was designed for a maximum head differential of 1 meter with 10 operating baffles, targeting head loss of 100 millimeters per cell. The head loss defines, at a given floor slope, the overall water velocity flowing between baffles.

Hydraulic assessment. Fishways are generally designed to operate within a given head loss range. Higher velocities are harder for fish to navigate, especially smaller fish. Therefore, it is standard practice to quantify the hydraulic performance of fishways to ensure that operational ranges remain within design specifications. 
Nam Beng Weir 1 and 2. An

engineer surveys the impact of $\mathrm{Nam}$ Beng Weir 1 (top) on the movement of fish. Members of the team composed of experts from NRI-AF and the two universities inspect Nam Beng Weir 2 (bottom) that creates stream blockage, affecting the migration of aquatic life (photos by Garry Thorncraft).
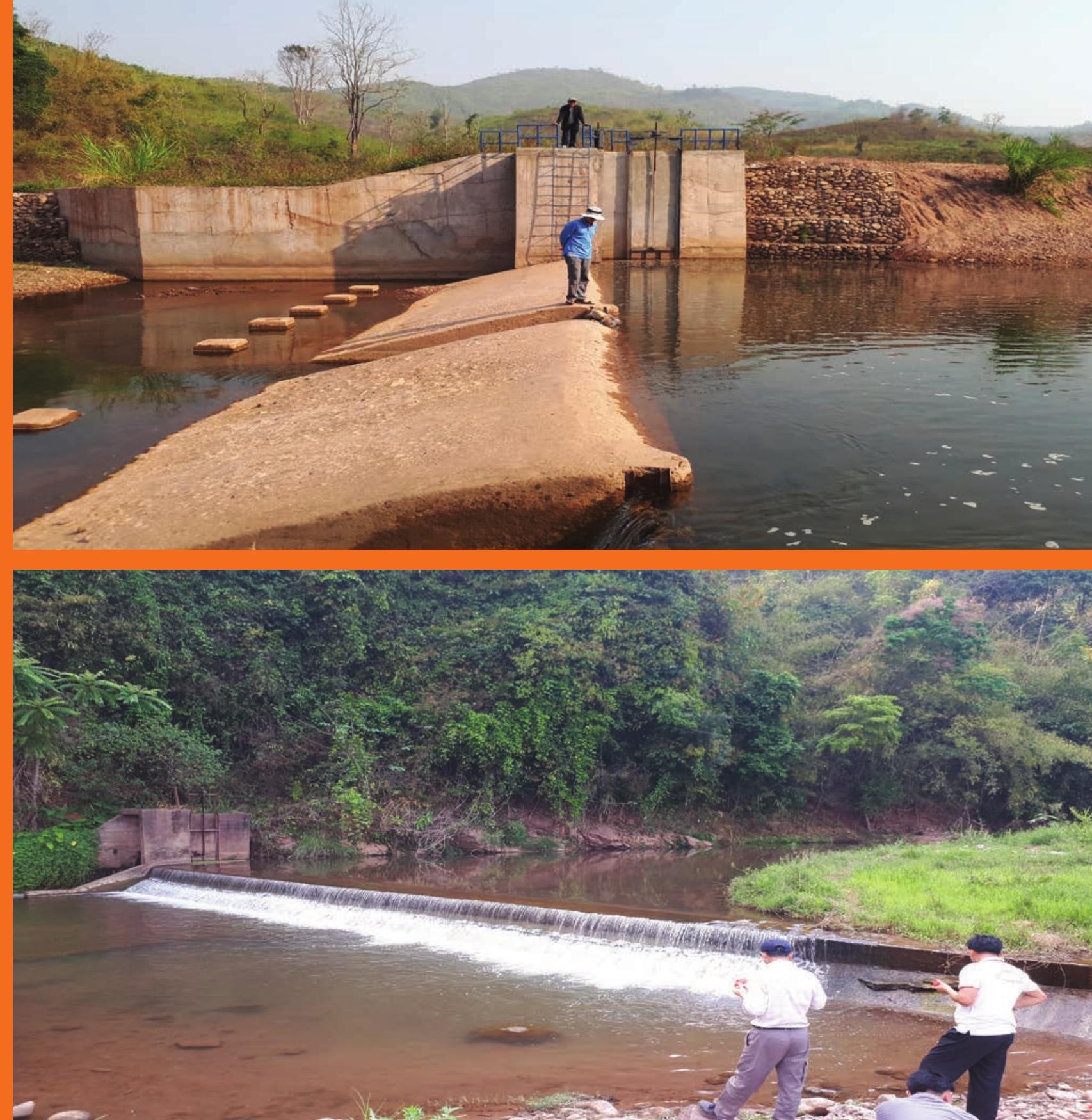
Sedimentation at weirs. Designs of fishways must consider environmental issues, such as upstream sedimentation (top) at Nam Beng and downstream sedimentation (bottom) at Nam Met (photos by Garry Thorncraft).

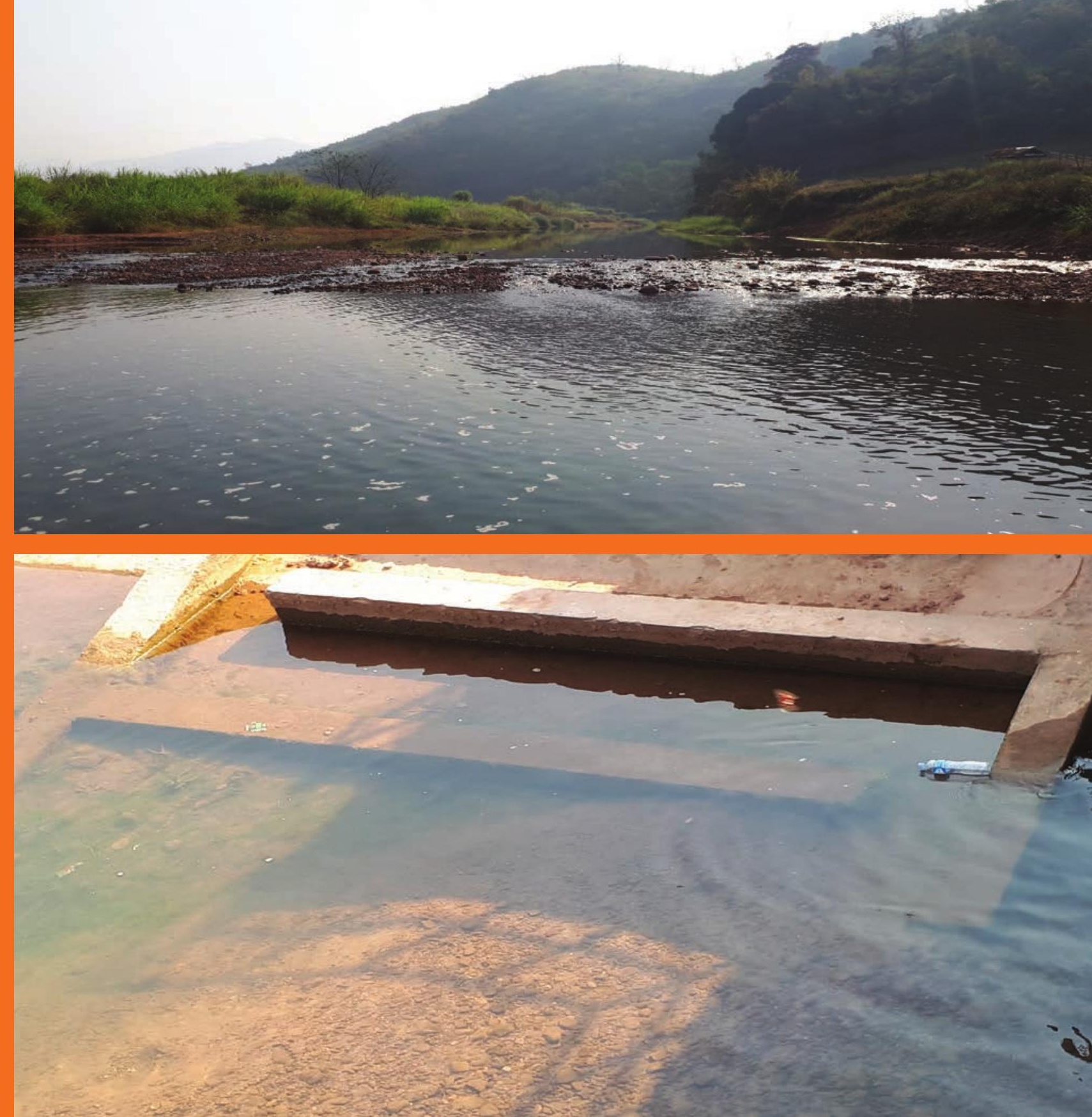




\section{Figure 10: Cross-Sectional View of the Baffles at the Nam Beng Weir Fishway}

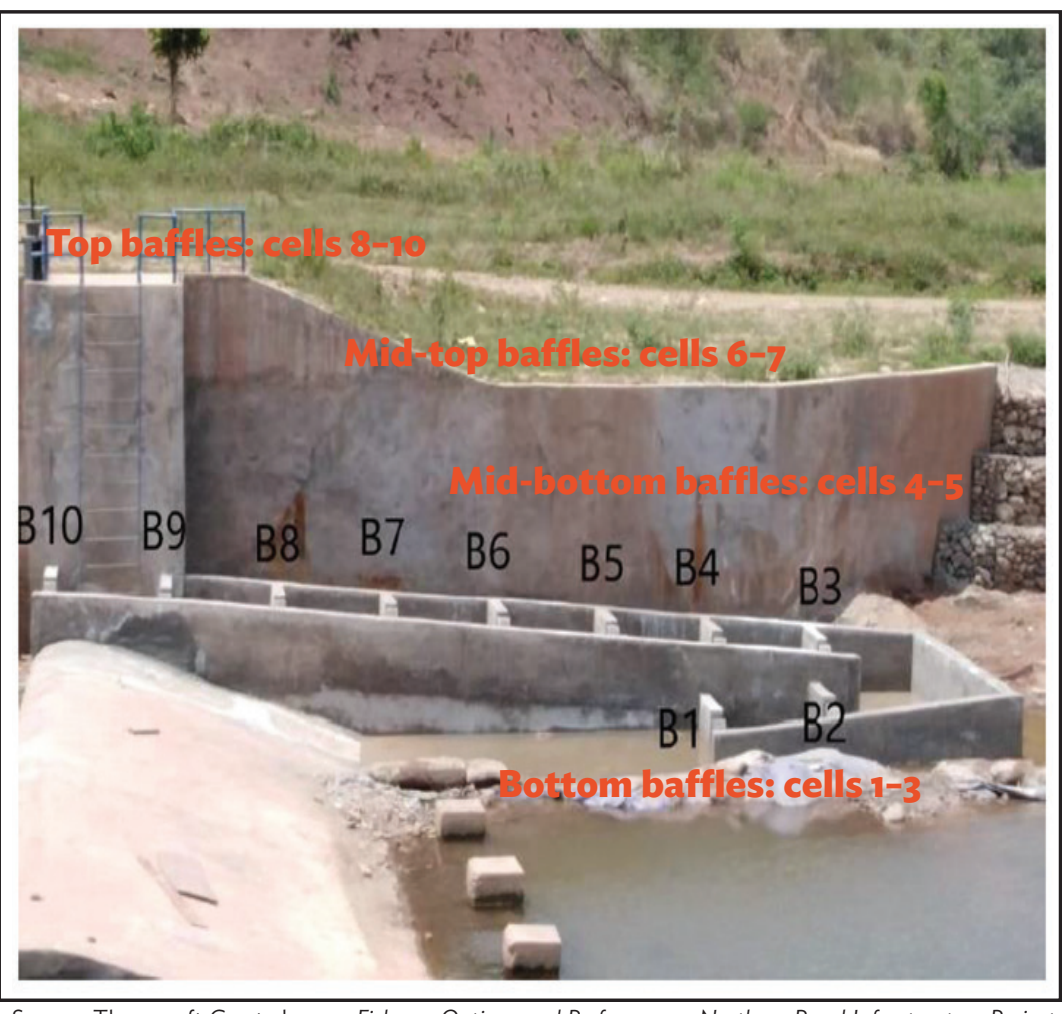

Source: Thorncraft G., et al. 2019. Fishway Options and Performance: Northern Rural Infrastructure Project National University of Laos Charles Sturt University.
The fishway was dewatered and cleared of fish. A screen was placed across the fishway exit. Water was then allowed to flow again to attract fish into the fishway. After 2 hours, a screen was inserted into the entrance to prevent new fish from entering the fishway. After 2 more hours, screens were inserted into baffles 8, 6 , and 4 to trap fish in the corresponding cell zones. The fishway was then dewatered for analysis. All fish within each zone were removed, measured, weighed, and identified to species prior to being released upstream.

Data analysis. The analysis sought to determine the number and size ranges of fish moving through the fishway. Average lengths, along with the maximum and minimum lengths, of the most common species were plotted from each sampling zone to determine if there was evidence of any smaller species or individuals having difficulty ascending the fishway. Total numbers of fish trapped within each zone were tabulated, fish were weighed, and differences in movement rates between day and night were logged.

\section{d. Results}

Hydraulic assessment. Overall, the total head (difference in height between the upstream and downstream water elevations) ranged from 10.5 centimeters $(\mathrm{cm})$ to $45.5 \mathrm{~cm}$ during the study sampling period (wet season: Jul-Aug 2019). There were 2 days where the structure was fully inundated, and the head difference between upstream and downstream was $0 \mathrm{~cm}$, hence the fish yield was not sampled. Within the fishway, head differential among baffles differed daily. Head losses at baffle 10 were as high as $41 \mathrm{~cm}$ and as 
low as $1 \mathrm{~cm}$, indicating that there was substantial debris building up on the upstream fishway exit. The inclusion of a trash rack on the upstream entrance to the fishway would resolve this issue. There was some evidence of hydraulic underperformance on some days on the downstream end of the fishway. Increasing the channel wall heights would prevent both headwater and tailwater levels overtopping the fishway, which reduces the design performance.

\section{e. General Fish Catches}

A total of 538 fish from 23 species were collected from the Nam Ben fishway over the sampling period. Of these, 116 fish from 16 species were collected at night and 422 fish from 22 species during the day. There was only a single species collected from night samples. Similarly, there were seven species collected during the day but not at night. All other species were collected from both night and day samples. Furthermore, from both day and night samples, more individual fish and species were collected from the 8-9 zone compared with other collection locations. From day samples, there were 11 species captured from all four fishway locations compared with only 7 species at night. Examples of the range of species caught in the fishway, which are used for direct household consumption and as an alternative livelihood income source, are provided in Figure 11.

The afternoon surveys caught significantly more fish than the morning surveys, and the overnight sampling sets collected less fish per hour than either daytime sets. The differences between time of day were exaggerated further up the fishway, with cells 8-9 always getting more fish than cells 6-7 and so on down to cells $1-3$ always collecting less fish (See Thorncraft et al. 2019 for detailed analyses).

The Nam Beng fishway successfully allowed passage for several species and individuals during the assessment, indicating that its construction, although not the ideal for this site, will provide benefits to upstream communities. Most of the species that passed the fishway were relatively small, but a few large species were migrating at the time of assessment. Overall, there was evidence that small fish were ascending the full length of the structure and that fish were seeking passage both during day and night. These multiple lines of evidence suggest that the experimental application of a trapezoidal fishway warrants further development at other sites.

A key factor driving effective fishway design is paying good design attention to entrance location, internal hydraulics, and head and tailwater ranges. Evidence suggests that the following aspects could be better designed for future fishways:

(i) Entrance drown-out. Fishway entrance drown-out occurs when the downstream weir water elevation floods the fishway. During these periods, (i) the fishway side walls overtop, (ii) the fishway entrance becomes more difficult for fish to locate, and (iii) water turbulence inside the fishway cells greatly increases. The main method of preventing this situation is to construct the fishway with high side walls and baffles that cannot be overtopped except when weir up and downstream elevations are approximately equal. 


\section{Figure 11: Fish Species Caught in Nam Ben Fishway}

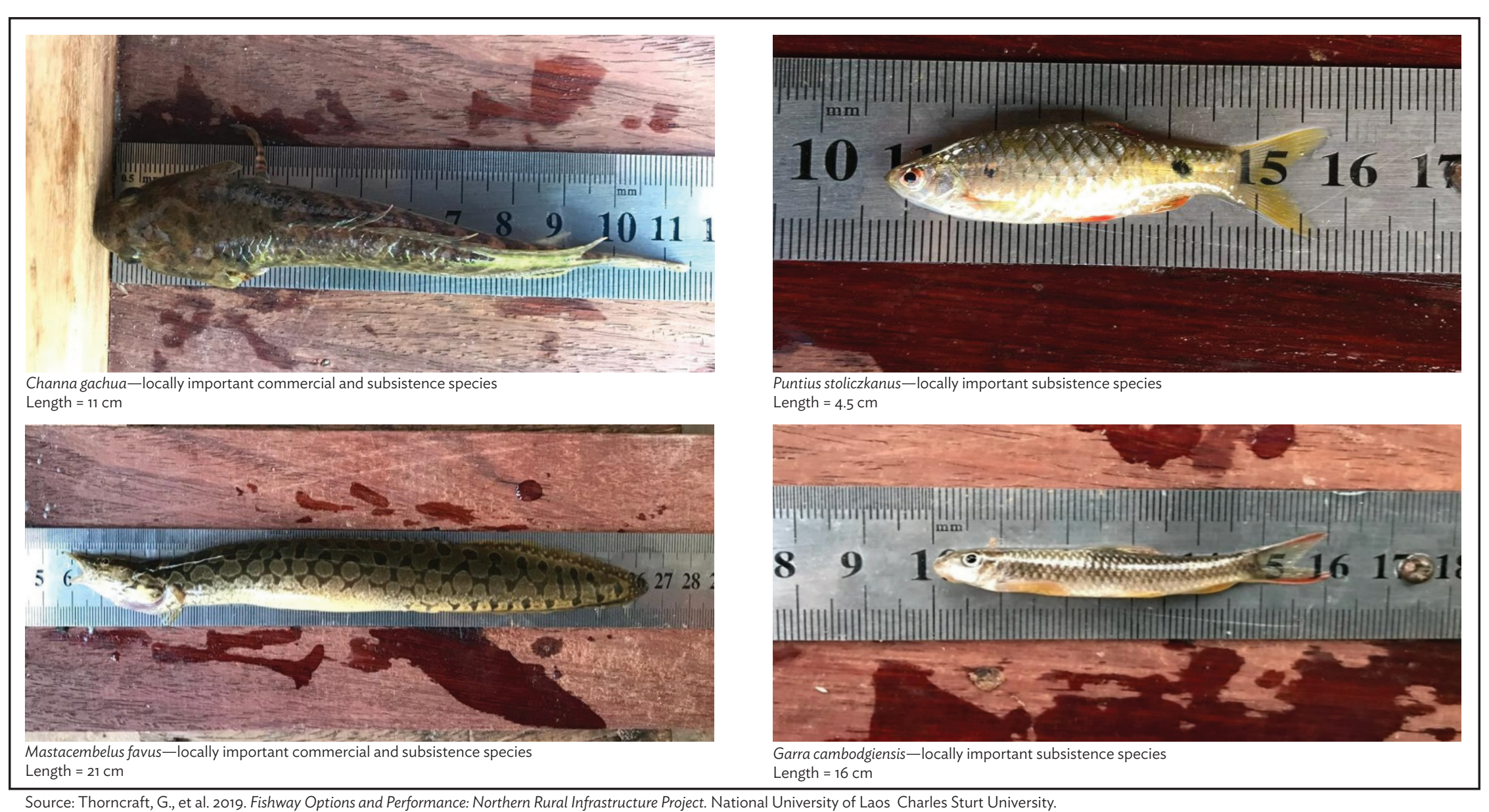

Source: Thorncraft, G., et al. 2019. Fishway Options and Performance: Northern Rural Infrastructure Project. National University of Laos Charles Sturt University. 
(ii) Variable head losses among cells. Exit head elevation rises to as high as $40 \mathrm{~cm}$, otherwise fishway baffles may become blocked. The primary way of preventing this problem is by fitting a large trash screen or trash deflector upstream of the fishway exit to prevent large debris from entering the fishway. However, this issue is best avoided by using good hydrological design data. With robust and accurate hydrology data, design features such as the floor invert, wall height, and entrance positioning can be determined with far greater accuracy. But such data are rare in rural Lao PDR.

Lessons learned from the NRI-AF were systematically incorporated into the concept and design of ADB's Sustainable Rural Infrastructure and Watershed Management Sector Project in the Lao PDR. A budget provision to cover the incremental costs of including fishways has been included in the project. All subprojects will be assessed for the potential benefits of incorporating fish passes into the diversion weirs and existing headworks. Where new weirs or headworks are to be constructed, all designs will include provisions for fishways. These subprojects will be assessed for site requirements by fishery experts, who will determine local fish species and their passage needs and provide indicative designs of structures and cost estimates to the engineering teams. 


\section{ADB Strategy 2030}

The biggest contribution of fishways is improving the overall mass of aquatic life, biodiversity, and food security within given catchments. According to Strategy 2030, "ADB will promote quality infrastructure investments that are green, sustainable, resilient, and inclusive." It also states: "Sustainable infrastructure investment will be central to achieving global commitments to address climate change and strengthen disaster risk management." This is based on the definition provided in the ADB Annual Report 2017: "Sustainable infrastructure is infrastructure that is designed, built, and operated to be durable, socially equitable, and economically and environmentally viable."

Fishways attributes of relatively low cost, contribution to ecosystem services, and conservation of wild fish stocks mean that while fishways increase land-based food sources, aquatic life, biodiversity, and food security are still sustainable, resilient, and inclusive. Table 2 shows how fishways contribute to some of the Strategy 2030 operational priorities.

\section{Table 2: Contributions of Fishways to the ADB Strategy 2030}

\begin{tabular}{|c|c|c|c|}
\hline Item & Operational Priorities & Approach in Strategy 2030 & Contribution of Fishways \\
\hline 1 & $\begin{array}{l}\text { Addressing remaining } \\
\text { poverty and reducing } \\
\text { inequalities }\end{array}$ & $\begin{array}{l}\text { ADB will increase the emphasis on human } \\
\text { development and social inclusion to address } \\
\text { the non-income dimensions of poverty. It will } \\
\text { help facilitate quality job creation, including } \\
\text { by small and medium-sized enterprises and } \\
\text { inclusive businesses. }\end{array}$ & $\begin{array}{l}\text { Fish are an essential dietary component and represent } \\
\text { a livelihood opportunity. For impoverished people, the } \\
\text { catching of wild fish or the raising of fish represents } \\
\text { both survival and commercial options. Fishways are } \\
\text { necessary for the preservation and maintenance of } \\
\text { wild fish and other aquatic life. }\end{array}$ \\
\hline 2 & $\begin{array}{l}\text { Accelerating progress in } \\
\text { gender equality }\end{array}$ & $\begin{array}{l}\text { ADB will support targeted operations } \\
\text { to empower women and girls, gender } \\
\text { mainstreaming that directly narrows } \\
\text { gender gaps, and operations with some } \\
\text { gender elements that incorporate a few } \\
\text { gender equality actions in the design and } \\
\text { implementation of ADB projects and } \\
\text { programs. }\end{array}$ & $\begin{array}{l}\text { Healthy wild fish stocks made possible by fishways } \\
\text { are easily caught and sold, and prepared as household } \\
\text { food, leaving more free time for girls and women (who } \\
\text { are often responsible for household food preparation) } \\
\text { for other more productive activities. }\end{array}$ \\
\hline
\end{tabular}




\begin{tabular}{|c|c|c|c|}
\hline Item & Operational Priorities & Approach in Strategy 2030 & Contribution of Fishways \\
\hline 3 & $\begin{array}{l}\text { Tackling climate change, } \\
\text { building climate and } \\
\text { disaster resilience, and } \\
\text { enhancing environmental } \\
\text { sustainability }\end{array}$ & $\begin{array}{l}\text { ADB will scale up support in these areas. } \\
\text { ADB will ensure that } 75 \% \text { of the number of its } \\
\text { committed operations. . . will be supporting } \\
\text { climate change mitigation and adaptation by } \\
2030 \text {. }\end{array}$ & $\begin{array}{l}\text { Under climate change, many food sources, including } \\
\text { fish, will come under extreme stress. Irrigation } \\
\text { programs can increase land-based food supplies, while } \\
\text { the inclusion of fishways as appropriate can enhance } \\
\text { the survival of aquatic supplies. }\end{array}$ \\
\hline 4 & $\begin{array}{l}\text { Promoting rural } \\
\text { development and food } \\
\text { security }\end{array}$ & $\begin{array}{l}\text { ADB will support efforts to improve } \\
\text { market connectivity and agricultural value } \\
\text { chain linkages. It will help DMCs increase } \\
\text { agricultural productivity and food security } \\
\text { by boosting farm and nonfarm incomes, } \\
\text { promoting the adoption of advanced } \\
\text { technologies and climate-smart agricultural } \\
\text { practices, and supporting the improvement } \\
\text { of natural resource management standards. } \\
\text { It will also help DMCs enhance food safety. }\end{array}$ & $\begin{array}{l}\text { Fishways are the very definition of climate-smart } \\
\text { practices and improved natural resource standards. } \\
\text { They are essential for food security and nutrition. They } \\
\text { are also potentially economically viable and have rapid } \\
\text { payback in some circumstances, as evidenced by the } \\
\text { application of the LMFST. }\end{array}$ \\
\hline 5 & $\begin{array}{l}\text { Strengthening } \\
\text { governance and } \\
\text { institutional capacity }\end{array}$ & $\begin{array}{l}\text { ADB will create an enabling environment } \\
\text { for sustainable growth. It will help countries } \\
\text { build resilience and respond to economic } \\
\text { shocks. ADB will uphold environmental and } \\
\text { social safeguards. }\end{array}$ & $\begin{array}{l}\text { Healthy wild aquatic life due to the inclusion of fishways } \\
\text { in irrigation schemes will enhance sustainable growth. } \\
\text { Exposing decision-makers to a range of analytical tools } \\
\text { that draw from multiple disciplines leaves long-run } \\
\text { benefits. }\end{array}$ \\
\hline
\end{tabular}




\section{J. Conclusions}

With the growing global population and competition over limited natural resources, fish provide a substantial source of protein in the global food chain. Despite the important role that inland fisheries play in the human diet and rural income generation, ensuring fish movement in the design of irrigation infrastructure projects is often overlooked. The challenge is exacerbated by the climate change impacts that threaten the already diminishing fish stocks, such as (i) increased water temperatures beyond the tolerating capacity of fish; (ii) more frequent floods; and (iii) increased risks of diseases, parasites, and harmful algal blooms.

With growing investments in irrigation infrastructure and modernization, it is critical to reconcile irrigation and fisheries agendas. In its 2030 strategy, ADB, as a leading multilateral development organization, emphasizes food security, poverty reduction, and climate resiliency. Continuity of fish productivity is essential in reaching all these goals. ADB should, therefore, ensure that its infrastructure projects pose no threat to the already diminishing fish population and, ultimately, to food security. Ideally, in new ADB infrastructure projects, effective fishway construction should be required, and retrofitting of existing structures to incorporate fishways should be explored.

The ADB NRI-AF in the Lao PDR proved that design integration of fishway into existing weirs was effective in ensuring a functional, low-cost measure to secure fish productivity. The input from fishery experts was crucial in helping the project's decision-makers appreciate the importance of fishways. In this regard, ADB's backup was instrumental in considering fishways in weir design. With the support of fishery experts, the NRI-AF developed fish-related impacts at concept stage and construction as part of the overall build rather than retrofitting, which is $25 \%$ more expensive.

The NRI-AF experience with designing and constructing fishways provided the empirical evidence needed to expand the investment in fishways into other ADB irrigation investment projects, most notably the Sustainable Rural Infrastructure and Watershed Management Sector Project in the Lao PDR. The project will construct fishways at each subproject involving an irrigation diversion weir and provide capacity building through a fish passages master class.

Fishway research is best carried out through adaptive management, which generates knowledge to build institutional and individual capacity, which is then translated into governance, policy, and practice. In strong adaptive management frameworks, research informs the development agenda that changes as new knowledge is generated to make sound development decisions. 


\section{References}

Baker, R., and B. Ruting. 2014. Environmental Policy Analysis: A Guide to Non-Market Valuation. Productivity Commission Staff Working Paper. Canberra.

https://www.pc.gov.au/research/supporting/non-marketvaluation/non-market-valuation.pdf.

Barange, M., T. Bahri, M. C. M. Beveridge, K. L. Cochrane, S. FungeSmith, and F. Poulain, eds. 2018. Impacts of Climate Change on Fisheries and Aquaculture: Synthesis of Current Knowledge, Adaptation and Mitigation Options. FAO Fisheries ad Aquaculture Technical Paper. No. 627. Rome: Food and Agriculture Organization of the United Nations.

http://www.fao.org/3/i9705en/i9705en.pdf.

Barlow, C., E. Baran, A. S. Halls, and M. Kshatriya. 2008. How Much of the Mekong Fish Catch Is at Risk from Mainstream Dam Development? Catch and Culture. 14 (3). pp. 16-21.

http://pubs.iclarm.net/resource_centre/WF_2041b.pdf.

Baumgartner, L., T. Marsden, J. Millar, G. Thorncraft, O. Phonekhampheng, D. Singhanouvong, K. Homsombath, W. Robinson, J. McPherson, K. L. Martin, and C. Boys. 2016. Development of Fish Passage Technology to Increase Fisheries Production on Floodplains in the Lower Mekong Basin. Australian Centre for International Agricultural Research. Canberra.

Baumgartner L. J., C. Barlow, M. Mallen-Cooper, C. Boys, T. Marsden, G. Thorncraft, O. Phonekhampheng, D. Singhanouvong,
Baumgartner, L., B. Zampatti, M. Jones, I. Stuart, and M. MallenCooper. 2014. Fish Passage in the Murray-Darling Basin, Australia: Not Just an Upstream Battle. Ecological Management \& Restoration. 15 (s1). pp. 28-39.

https://onlinelibrary.wiley.com/doi/full/10.1111/emr.12093.

Bednarek, A. T. 2001. Undamming Rivers: A Review of the Ecological Impacts of Dam Removal. Environmental Management. 27 (6). pp. 803-814.

https://www.academia.edu/5149219/Undamming_Rivers_A_ Review_of_the_Ecological_Impacts_of_Dam_Removal.

Conallin, J. C., L. J. Baumgartner, Z. Lunn, M. Akester, N. Win, N. N. Tun, M. M. M. Nyunt, A. M. Swe, N. Chan, and I. G. Cowx. 2019. Migratory Fishes in Myanmar Rivers and Wetlands: Challenges for Sustainable Development between Irrigation Water Control Infrastructure and Sustainable Inland Capture Fisheries. Marine and Freshwater Research. 70 (90). pp. 1241-1253.

https://www.publish.csiro.au/mf/MF19180.

Cooper, B., L. Crase, and L. J. Baumgartner. 2019. Estimating Benefits and Costs: A Case of Fish Passages in Lao PDR and the Development of the Lower Mekong Fishway Support Tool. Marine and Freshwater Research. 70 (9). pp. 1284-1294. https://www.publish.csiro.au/mf/MF19156.

Hortle, K.G. 2007. Consumption and the Yield of Fish and Other Aquatic Animals from the Lower Mekong Basin. MRC Technical 
Paper. No. 16. Vientiane: Mekong River Commission.

http://www.mrcmekong.org/assets/Publications/technical/techNo16-consumption-n-yield-of-fish.pdf.

Intergovernmental Panel on Climate Change. 2019. Special Report on the Ocean and Cryosphere in a Changing Climate.

https://www.ipcc.ch/srocc/.

Intergovernmental Panel on Climate Change. 2019. Summary for Policymakers. In H.-O. Pörtner, eds. IPCC Special Report on the Ocean and Cryosphere in a Changing Climate.

https://www.ipcc.ch/srocc/chapter/summary-for-policymakers/.

Lynch, A. J., L. J. Baumgartner, C. A. Boys, J. Conallin, I. G. Cowx, C. M. Finlayson, P. A. Franklin, Z. Hogan, J. D. Koehn, M. P. McCartney, G. O'Brien, K. Phouthavong, L. G. M. Silva, C. A. Tob, J. ValboJørgensen, V. V. An, L. Whiting, A. Wibowo, and P. Duncan. 2019. Speaking the Same Language: Can the Sustainable Development Goals Translate the Needs of Inland Fisheries into Irrigation Decisions? Marine and Freshwater Research. 70 (9). pp. 1211-1228. https://www.publish.csiro.au/mf/pdf/MF19176.

Nam, S., S. Phommakone, L. Vuthy, T. Samphawamana, H. S. Nguyen, M. Khumsri, P. B. Ngor, K. Sovanara, P. Degen, and P. Starr. 2015. Lower Mekong Fisheries Estimated To Be Worth around \$17 Billion a Year. Catch and Culture. 21 (3). pp. 4-7.

http://www.mrcmekong.org/assets/Publications/Catch-andCulture/CatchCultureVol-21.3.pdf.
Oldani, N. O., and C. R. Baigún. 2002. Performance of a Fishway System in a Major South American Dam on the Parana River (Argentina-Paraguay). River Research and Applications. 18 (2). pp. 171-183.

https://onlinelibrary.wiley.com/doi/abs/10.1002/rra.640.

Rice, W. M. Roy, L. Crase, and B. Coope. 2019. Achieving Fish Passage Outcomes at Irrigation Infrastructure; A Case Study from the Lower Mekong Basin. Aquaculture and Fisheries.

https://www.sciencedirect.com/science/article/pii/ S2468550X1830159X.

Thorncraft, G., and J. H. Harris. 2000. Fish Passage and Fishways in New South Wales: A Status Report. Cooperative Research Centre for Freshwater Ecology Technical Report. 1/2000. Canberra, Australia. https://pdfs.semanticscholar.

org/8812/005625e9d639ae8aa91dbf1f877a335f5aod.pdf? ga $=2.36172064 .1694021025 .1587109440-1571659318.1587109440$.

Thorncraft, G., L. J. Baumgartner, P. Vorsane, W. R. Robinson, and N. Ning N. 2019. Fishway Options and Performance: Northern Rural Infrastructure Project. National University of Laos and Charles Sturt University.

WorldFish. Why Fish?. https://www.worldfishcenter.org/why-fish. 




\section{Diversion Weirs and Fish Passages For Small-Scale Irrigation in the Lao People's Democratic Republic}

Irrigation schemes provide water resources and improve agricultural production, but careful consideration must be taken to prevent undermining aquatic life. The provision of fishways aid in the uninterrupted movement of fish within an ecosystem where irrigation schemes are applied for land-based food production. This publication contains foundational information on the importance and features of fish passages and fishways for irrigation investments, with examples of successful application of fish passage technology in the Lao People's Democratic Republic. It serves as a useful reference for planning, designing, and implementing cost-effective and sustainable responsible irrigation projects, water resource management, and food production.

\section{About the Asian Development Bank}

ADB is committed to achieving a prosperous, inclusive, resilient, and sustainable Asia and the Pacific, while sustaining its efforts to eradicate extreme poverty. Established in 1966, it is owned by 68 members -49 from the region. Its main instruments for helping its developing member countries are policy dialogue, loans, equity investments, guarantees, grants, and technical assistance.

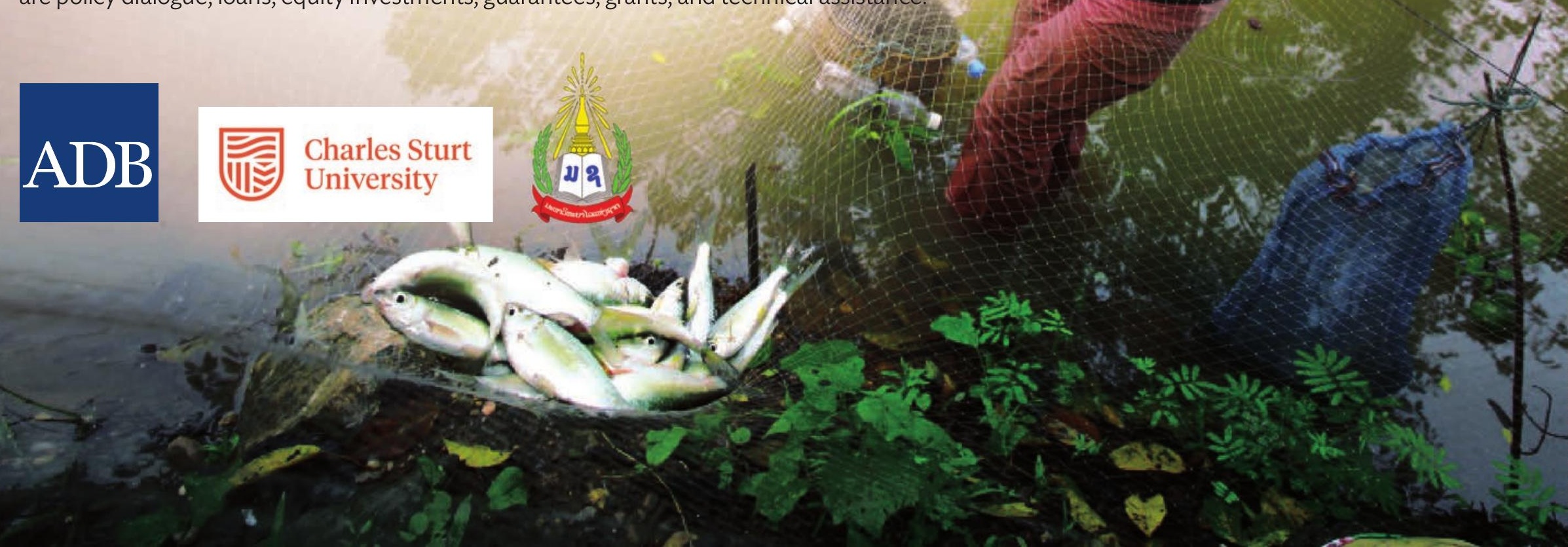

